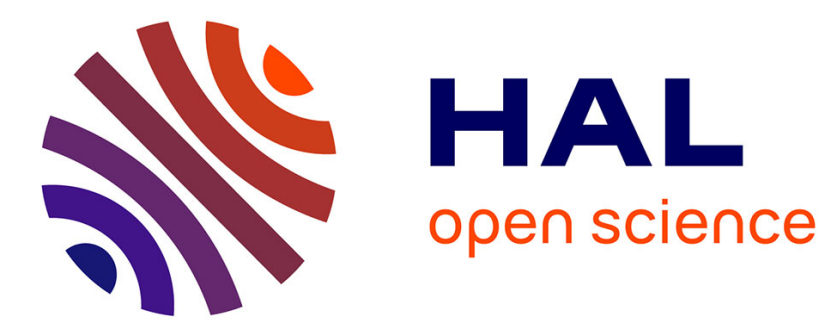

\title{
Stratigraphy and Palaeopedology of the Palaeolithic Cave Site of Combe-Saunière, Southwest France
}

\author{
Aurelie Ajas, Pascal Bertran, Laurent Lemée, Alain Queffelec
}

\section{To cite this version:}

Aurelie Ajas, Pascal Bertran, Laurent Lemée, Alain Queffelec. Stratigraphy and Palaeopedology of the Palaeolithic Cave Site of Combe-Saunière, Southwest France. Geoarchaeology: An International Journal, 2013, 28 (5), pp.432-449. 10.1002/gea.21451 . hal-02264048

\section{HAL Id: hal-02264048 \\ https://hal.science/hal-02264048}

Submitted on 11 Jun 2020

HAL is a multi-disciplinary open access archive for the deposit and dissemination of scientific research documents, whether they are published or not. The documents may come from teaching and research institutions in France or abroad, or from public or private research centers.
L'archive ouverte pluridisciplinaire HAL, est destinée au dépôt et à la diffusion de documents scientifiques de niveau recherche, publiés ou non, émanant des établissements d'enseignement et de recherche français ou étrangers, des laboratoires publics ou privés. 


\title{
Stratigraphy and Palaeopedology of the Palaeolithic Cave Site of
}

\section{Combe-Sauniere, Southwest France}

\author{
Aurelie Ajas ${ }^{1}$, Pascal Bertran ${ }^{1,2}$, Laurent Lemee $^{3}$ and Alain Queffelec ${ }^{1}$ \\ ${ }^{1}$ Universite de Bordeaux-CNRS, Talence, France \\ ${ }^{2}$ INRAP, Pessac, France \\ ${ }^{3}$ Universite de Poitiers - CNRS, Poitiers cedex, France'
}

\section{ABSTRACT}

The sequence of Combe-Sauniere (southwest France) has been studied with' a large suite of methods, including micromorphology, geochemistry, magnetic susceptibility, and organic matter (OM) analysis in order to document the postdepositional processes that occurred during the last climatic cycle at the cave entrance. This study shows that intense weathering together with the accumulation of $\mathrm{OM}$ and phosphates by cave animals and others vectors (including humans) occurred during the phases of low clastic sedimentation. During the latter part of Marine Isotope Stage (MIS) 3, the Aurignacian and Gravettian humus-bearing levels, which may be classified as cryoturbated leptosols, show incomplete decalcification and are dominated by poorly evolved forms of phosphates (bone fragments, coprolites). Phosphatized cambic B-horizons formed at the beginning of MIS 3 and the Early Glacial and may reflect longer periods of pedological modification. The molecules identified by the analysis of the OM extracted from the Chatelperronian level derive mostly from the degradation of vegetal matter, most notably from conifers and mosses, in addition to bacteria and fungi. The Last Interglacial s.l. (MIS 5) is typified by the development of a phosphatized illuviated B-horizon. Intense weathering together with phosphate leaching and precipitation took place in this soil, forming thick apatite- $\mathrm{CaOH}$ crusts. Although the poor chronological resolution prevents us from drawing clear conclusions as to the respective roles of the factors involved, phosphate accumulation and weathering seem to be controlled primarily by the duration of the soil-forming periods. This study strongly suggests that a climatic signal has been recorded in the deposits.

\section{INTRODUCTION}

Sedimentary sequences at the entrance of caves and rockshelters are among the main archives in Europe that allow documentation of the succession of prehistoric technocomplexes during the Pleistocene. As a consequence they have long interested geoarchaeologists and a great deal of effort has been made to derive palaeoenvironmental data from these sediment archives. During the last few decades, both analytical improvements and a wider knowledge of the processes that occur in presentday rockshelters and cave entrances have led to a better understanding of these Pleistocene sequences. These include mainly (1) investigations at the microscopic scale of intact sediment samples (mi cromorphology, scanning electron microscopy), which provide detailed views of the composition and post-depositional evolution of sediments (among others Goldberg, 1979; Bull \& Goldberg, 1985; Courty, Goldberg, \& Macphail, 1989), (2) the use of a wide array of techniques for chemical and mineralogical determination (Woodward, 1997; Karkanas et al., 2000; Goldberg \& Sherwood, 2006), (3) documentation of sedimentary processes acting on talus and associated lithofacies (e.g., Blair \& Mcpherson, 1994; Van Steijn et al., 1995; see also a review in Bertran et al., 2004), and (4) documentation of biogenic processes, and particularly the accumulation of phosphates and the post- 
depositional transformations they cause (Martini \& Kavalieris, 1978; Horwitz \& Goldberg, 1989; Karkanas et al., 2000, 2002; Shahack-Gross et al., 2004; Bos, 2012). In spite of these developments, there is a lack of consensus with regards to the interpretation of the deposits, and particularly to their suitability for providing information on palaeoclimates. Though most authors recognize the climatic significance of some types of depositional events or sediment perturbations, such as freeze-thaw induced processes (cryoturbation, periglacial solifluction, e.g., Goldberg, 1979; Courty \& Vallverdu, 2001; Karkanas, 2001; Bertran et al., 2010), many view sedimentation and post-depositional modifications in caves entrances to reflect mostly local factors that are impossible to disentangle from the regional climatic signal (for a summary of this point of view, see Goldberg \& Sherwood, 2006). In line with this conception, post-depositional transformations in these contexts are usually referred to as diagenesis, a term that encompasses "all changes in sediments occurring from the moment of deposition, continuing through compaction, lithification and beyond [until] the onset of metamorphism" (Ali et al., 2010). Although the soilforming processes as understood by pedologists (USDA, 1999; FAO-WRB, 2006) are part of diagenesis, this also includes all low-temperature transformations occurring at greater depth in sedimentary basins, which are poorly dependant on the environmental conditions prevailing at the ground surface (Worden \& Burley, 2003). The widespread use of "diagenesis" rather than the more restricted term "pedogenesis" in cave studies lends weight to the idea that most of the observed post-depositional modifications, including weathering, are not controlled by biological or physical environmentally dependant factors and, therefore, cannot provide reliable data on past climates. Recently, however, Pirson et al. $(2006,2012)$ have highlighted the similarities between Upper Pleistocene cave sequences in Belgium and those documented from regional open-air sites in the loess belt. In particular, the main palaeosols in the loess deposits, which date to the Last Interglacial, the Early Glacial, and the Middle Pleniglacial, were found to have counterparts in cave entrances, strongly suggesting that both types of records were controlled by common, climatically driven factors. Similar interpretations, pointing out the probable role of Dansgaard-Oeschger (DO) interstadials on the formation of weathered humic horizons within the last Pleniglacial (dominantly clastic) deposits, have also been proposed for two sites in southwest France (Bertran et al., 2008; Lenoble \& Agsous, 2012).

Following these findings, the sequences covering the last glacial cycle in rockshelters and cave entrances in the limestone massifs of southwest France have been critically reexamined. It has been found that they typically exhibit the following succession: (1) thick reddish to brown layers yielding Mousterian and Chatelperronian industries, (2) alternating coarse-grained clastic and finer-grained brown to black layers yielding Upper Palaeolithic (the classical "black" Aurignacian to Middle Gravettian layers identified by French archaeologists), (3) dominantly light-colored clastic deposits corresponding to the Last Glacial Maximum, and finally (4) the reddish to black Lateglacial-Holocene soil with Late Palaeolithic to medieval levels and/or humus-rich anthropogenic colluvium at the top (Peyrony, 1934; de Sonneville-Bordes, 1958; Figure 1). Because of the accessibility of the sections and the significant number of available numerical dates, the recently excavated Combe-Sauniere site (Geneste \& Chadelle, 1996) has been chosen to reappraise this type of sequence using a palaeopedological approach. Although this site is far from the thickest stratigraphy in the region, it provides a representative sedimentary and pedological record spanning the whole of the last glacial cycle. 

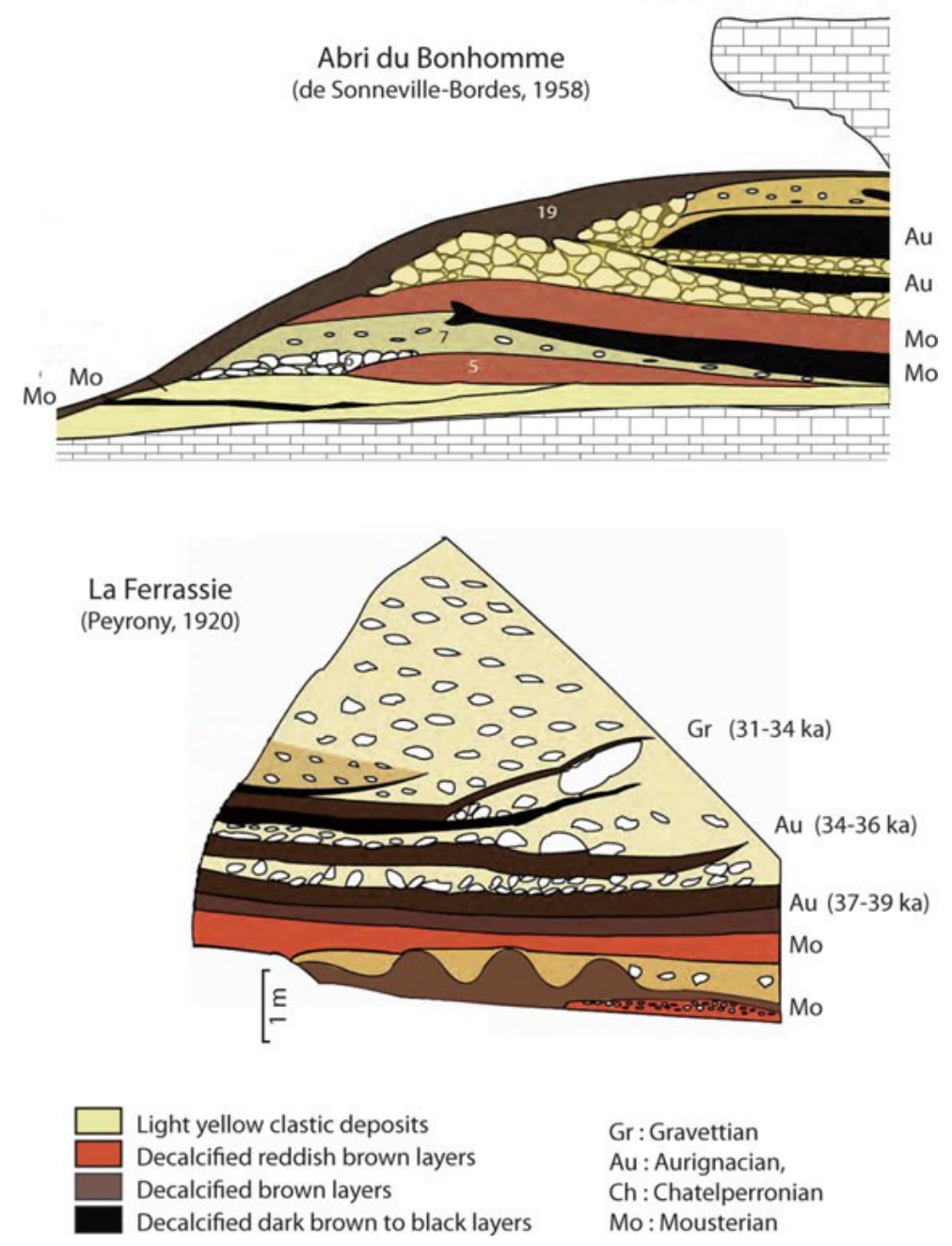
Gr: Gravettian
Au : Aurignacian,
Ch : Chatelperronian
Mo: Mousterian

Figure 1 Schematic stratigraphy of the Abri du Bonhomme and La Ferrassie rockshelter deposits.

\section{MATERIAL AND METHODS}

\section{Geological Setting, Archaeology}

Combe Sauniere was discovered fortuitously in 1976 and was excavated between 1978 and 1996 under the supervision of J.M. Geneste and J.P. Chadelle. The site is situated within a small cave located in the Isle valley, a tributary of the Dordogne River, a few kilometers from Perigueux (southwest France; Figure 2). The cavity opens' into an Upper Turonian limestone (bioclastic calcarenite) wall, which is oriented to the southwest and partially covered by thick colluvium. The plateau above the cavity is covered by red Eocene sands and clays, and small patches of Lower Pleistocene gravels (Le Pochat et al., 1979). 


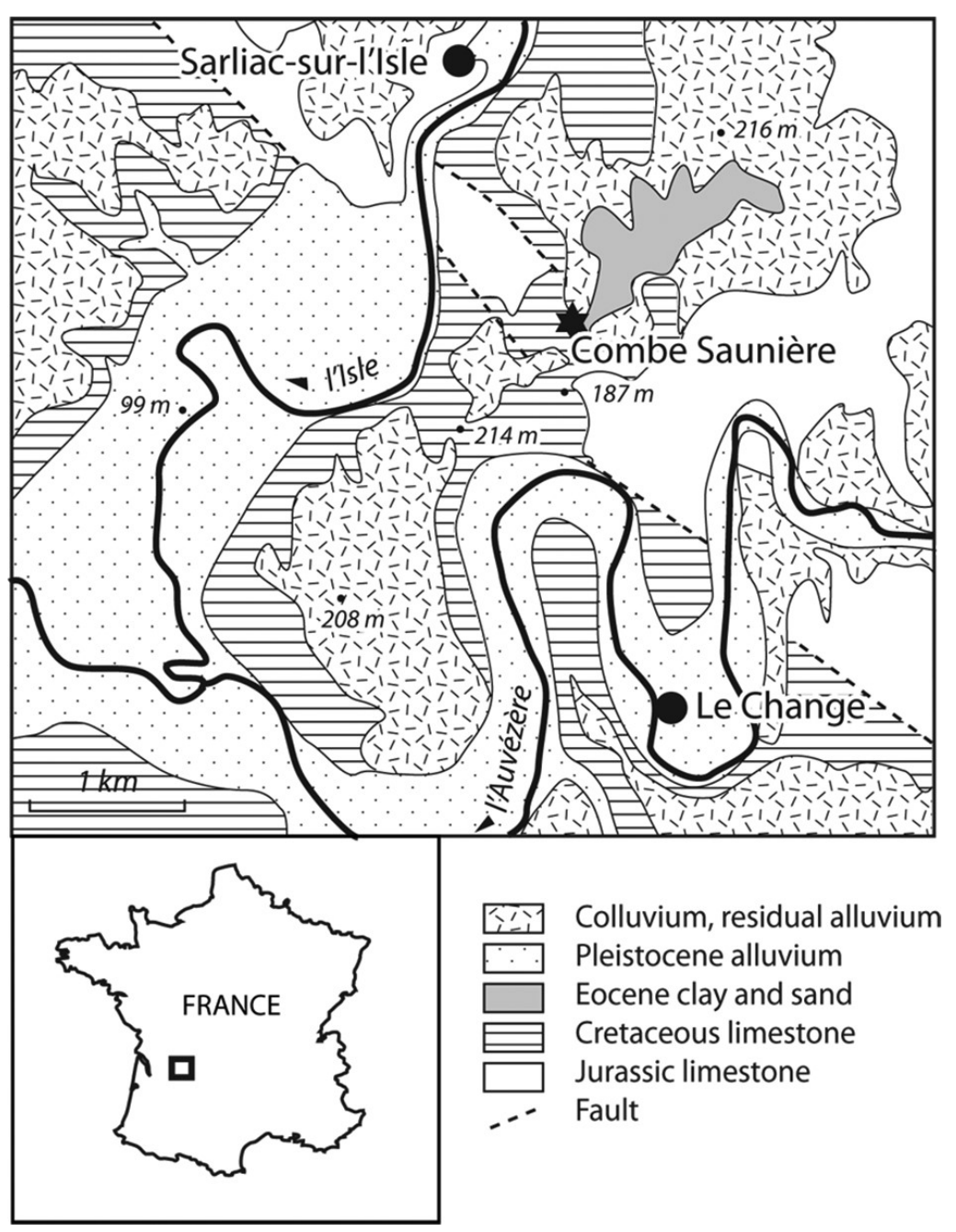

Figure 2 Simplified geological map, from Pochat et al. (1979), and site location.

The karst feature developed along a former joint and forms a chamber 4-5 $\mathrm{m}$ wide, $10 \mathrm{~m}$ long, and with a height greater than $4 \mathrm{~m}$ (the limestone floor has not been reached by the excavation trenches). The detrital talus at the cave entrance yielded several archaeological levels that span the entire last glacial cycle. They comprise Mousterian, Chatelperronian, Aurignacian, So-^ lutrean, and Magdalenian levels. Protohistoric and medieval artifacts were also recovered from the upper layers. The investigated section is today in the front area of the cave, but the presence of large blocks in the sequence indicates that the limestone roof retreated progressively during the last glacial. Thus, the lower levels were probably originally located deeper in the cavity by at least a few meters. Nonetheless, the whole sequence can be considered as belonging to a cave entrance envi ronment. Since the upper part of the sequence, including the Solutrean levels, was totally excavated before our study, it could not be sampled and our analysis focuses on the archaeological levels from the Mousterian to the Gravettian. 


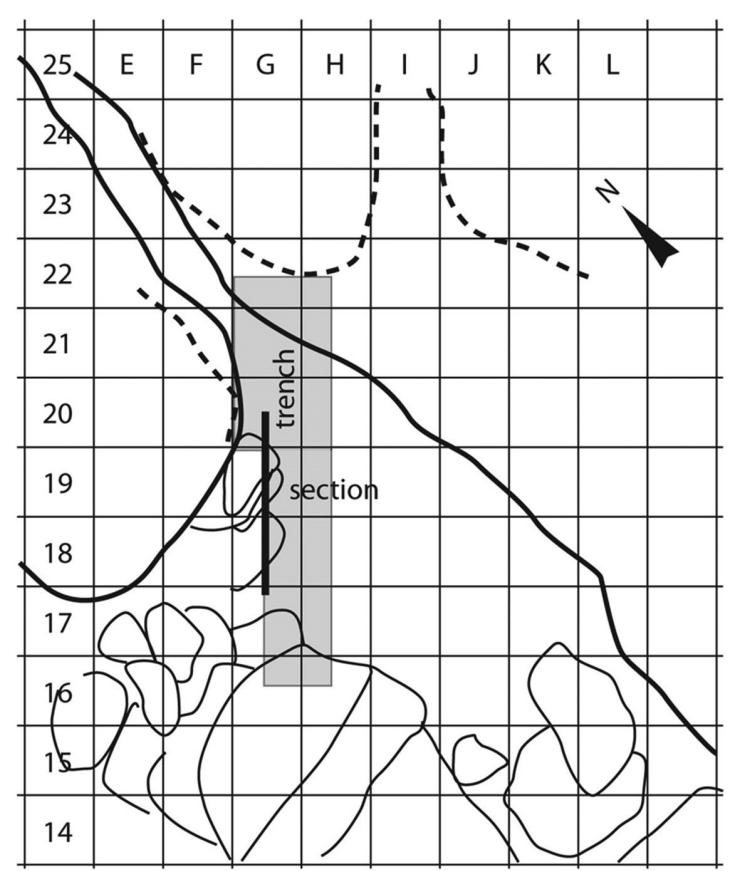

Figure 3 Location of the sampled section in the site. Solid and dashed lines correspond to the overhang and wall limits,

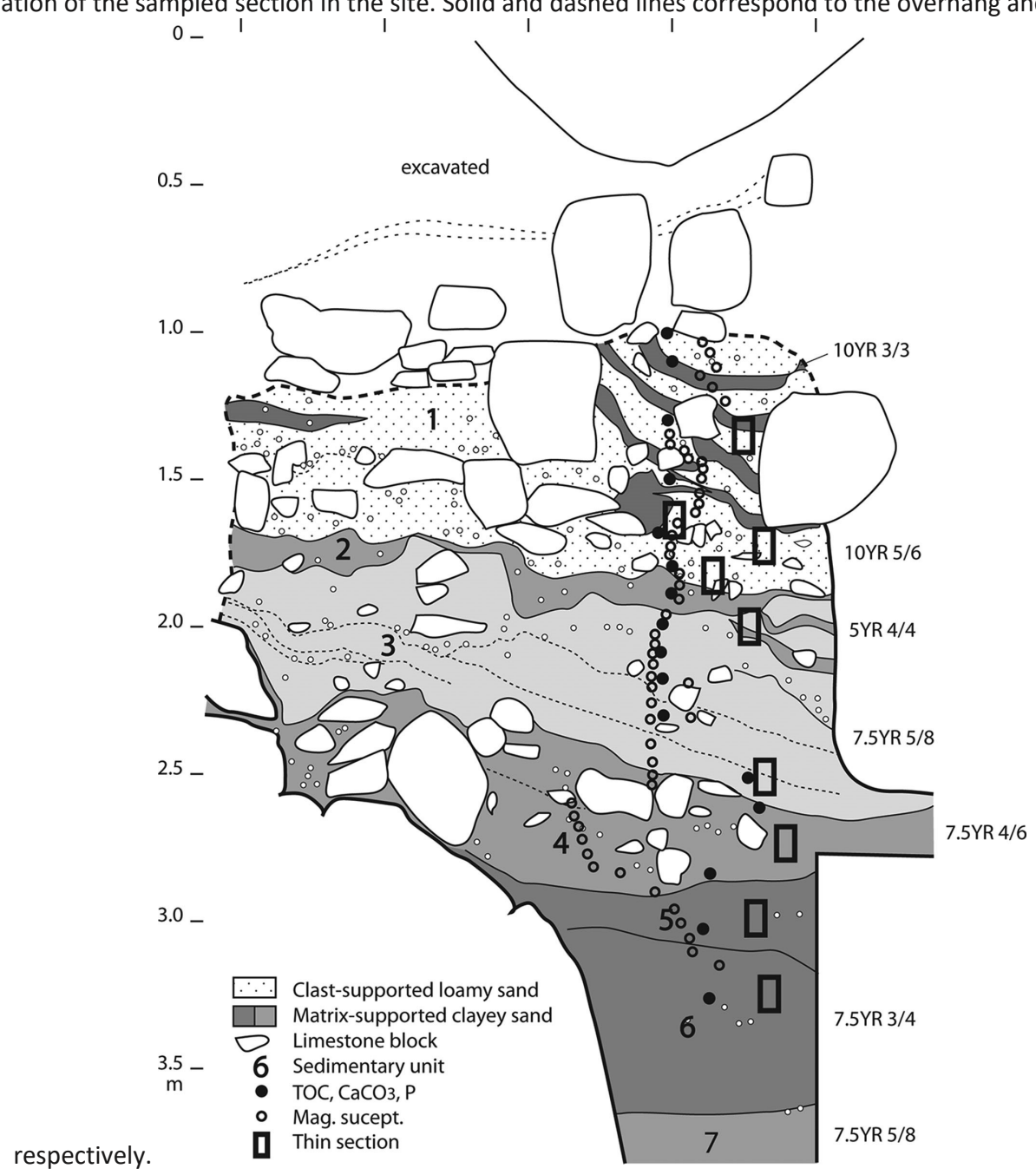

Figure 4 Stratigraphy and location of the samples for micromorphology and measurement of $\mathrm{TOC}, \mathrm{CaCO}_{3}, \mathrm{P}$, and magnetic susceptibility. 


\section{Methods}

The longitudinal section located in the western part of the entrance was sampled for analysis (Figures 3 and 4). After field examination of the section, sediment samples were taken for micromorphology and geochemistry studies, including measurement of phosphorus $(\mathrm{P})$, carbonate $\left(\mathrm{CaCO}_{3}\right)$, total organic carbon (TOC), and organic matter (OM) analysis. Large thin sections were prepared from undisturbed blocks of sediment vacuum impregnated with a polyester resin following the method described by Guilloré (1980). The terminology employed' to describe the micromorphological observations is taken from Bullock et al. (1985). TOC and $\mathrm{CaCO}_{3}$ were measured by pyrolysis $\left(1500^{\circ} \mathrm{C}\right)$ coupled with infrared spectrometry using a Leco CS-125 analyzer on the fraction $<2 \mathrm{~mm}$. Phosphorus was measured by titration with a colorimetric method according to the protocol proposed by Murphy and Riley (1962). The mineralogy of all the samples $(<2 \mathrm{~mm}$ ) was analyzed by X-ray diffraction (XRD) using a PANalytical $X^{\prime}$ pert MDP (Cu, $40 \mathrm{kV}, 40 \mathrm{~mA}$ ). Mineral identification was achieved with the software Eva (Bruker AXS) coupled with the JCPDSICDD mineral database and the software Crystal Sleuth coupled with the RRUFF database (Downs, 2006). Selective identifications were also made with a confocal Raman microspectrometer SENTERRA (Bruker Optics) on polished slabs. Spectra were obtained using a 532 $\mathrm{nm}$ exciting line with a resolution between 3 and $5 \mathrm{~cm}^{-1}$ and compared to the RRUFF project database (Downs, 2006). Chemical formulas are given according to the IMA/CNMNC list (IMA, 2009). Volumetric magnetic susceptibility was measured on the section with a portable Bartington MS2 equipped with a MS-2F probe.

Two samples for geochemical analysis of OM were taken from layer 2 (Chatelperronian level) on the opposite wall of the trench, because of better development and darker appearance. The OM was characterized by diffuse reflectance infrared Fourier transform spectroscopy (DRIFTS). Spectra were recorded in $\mathrm{KBr}$ between 4000 and $600 \mathrm{~cm}^{-1}$ on a Perkin-Elmer Spectrum 1000 spectrometer. Lipids were extracted with dichloromethane/methanol $2 / 1(\mathrm{v} / \mathrm{v})$ using accelerated solvent extractor (ASE 100, Dionex). The total lipid extracts were derivatized prior to GC/MS (where GC is gas chromatograph and MS is mass spectrometer) analysis. Alkanols and sterols were converted to acetates using acetic anhydride/pyridine, whereas fatty acids were methylated using trimethylsilyldiazomethane. GC/MS analysis was performed using a ThermoFisher Focus GC coupled with a DSQ II quadrupole MS. GC separations were conducted using a BPX5 (SGE) capillary column ( $30 \mathrm{~m}$ long, $0.25 \mathrm{~mm}$ of internal diameter). The column temperature was programmed from 60 to $300^{\circ} \mathrm{C}$ at a rate of $5^{\circ} \mathrm{C} \mathrm{min}^{-1}$ and held for $30 \mathrm{~min}$ at $300^{\circ} \mathrm{C}$. The compounds were identified on the basis of their GC retention times and by comparison of their mass spectra with those of standards and with data from the literature. The macromolecules were characterized by analytical pyrolysis and thermochemolysis (pyrolysis with in situ methylation). Analytical pyrolysis was performed at $650^{\circ} \mathrm{C}$ on a CDS Pyroprobe 5150 equipped with a 5250 autosampler. About $50 \mathrm{mg}$ of the sample was introduced into a 2 i.d. $\times 40 \mathrm{~mm}$ quartz tube filled with quartz wool and inserted into the autosampler. Thermochemolysis was performed with the same device used for pyrolysis. Approximately $10 \mathrm{mg}$ of sample were moistened with a tetramethylammonium hydroxide (TMAH; Aldrich) solution $(75 \mu \mathrm{L}, 50 \% \mathrm{w} / \mathrm{w}$ in methanol) prior to pyrolysis. 


\section{RESULTS}

\section{Lithostratigraphy}

Different lithostratigraphic units have been recognized in the site's stratigraphic sections. These are, from top to bottom (Figure 4), as follows:

Layer 1 (archaeological levels VI and V): 1-m thick clast-supported layer composed of angular limestone fragments and a yellowish-brown (7.5YR 5/4 to 10YR 5/9) carbonate-rich silty sand matrix (Figure 5A). A few darker (10YR 3/3) cryoturbated layers are intercalated within the clastic deposits. At the microscopic scale, the dark color appears to be due both to staining of the clay particles by organic compounds and to scattered charcoal dust (contrasting microparticles). Bone and charred bone fragments together with flint artifacts are common. Some phosphate grains interpreted as coprolite fragments (Horwitz \& Goldberg, 1989; Rodriguez, Rego, \& Cortizas, 1995) are visible. Thick silt cappings developed on coarse elements (Figure 6A) are associated with clean sand intercalations and a platy structure. Abundant small pits lined with thin organic coatings reflect incipient bioalteration of the limestone fragments. At the top of the unit, the cappings and the platy structure have been partially destroyed by bioturbation. This unit contains Aurignacian and Gravettian industries.
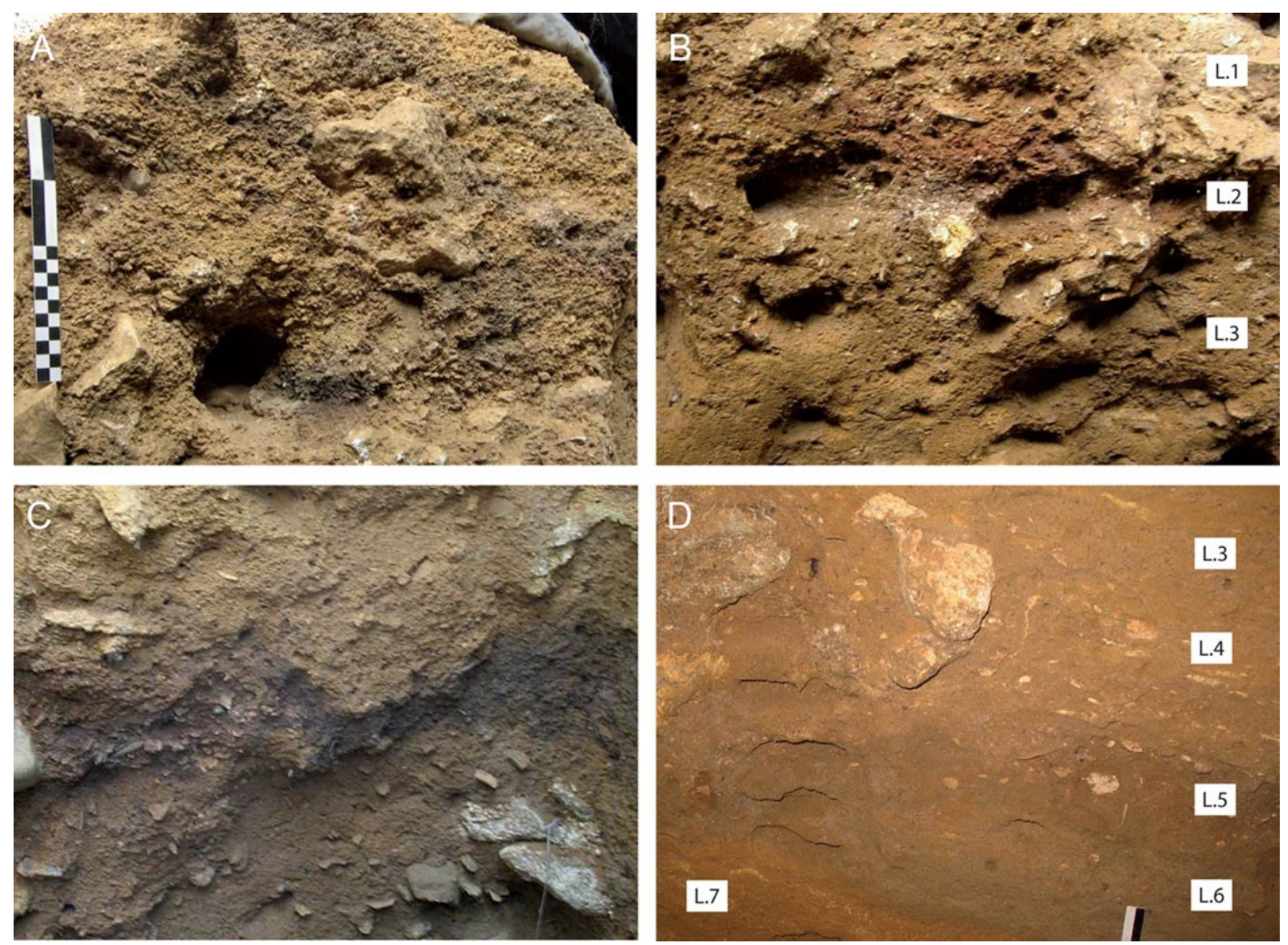

Figure 5 (A) View of layer 1, the scale is $20 \mathrm{~cm}$ long; (B) view of layers 1-3, the height of the section is c. $1 \mathrm{~m}$; (C) view of the Chatelperronian dark brown` level sampled for organic matter analysis, the height of the section is c. $1.3 \mathrm{~m}$; (D) view of layers $3-7$, the height of the section is $c$. $1 \mathrm{~m}$. 

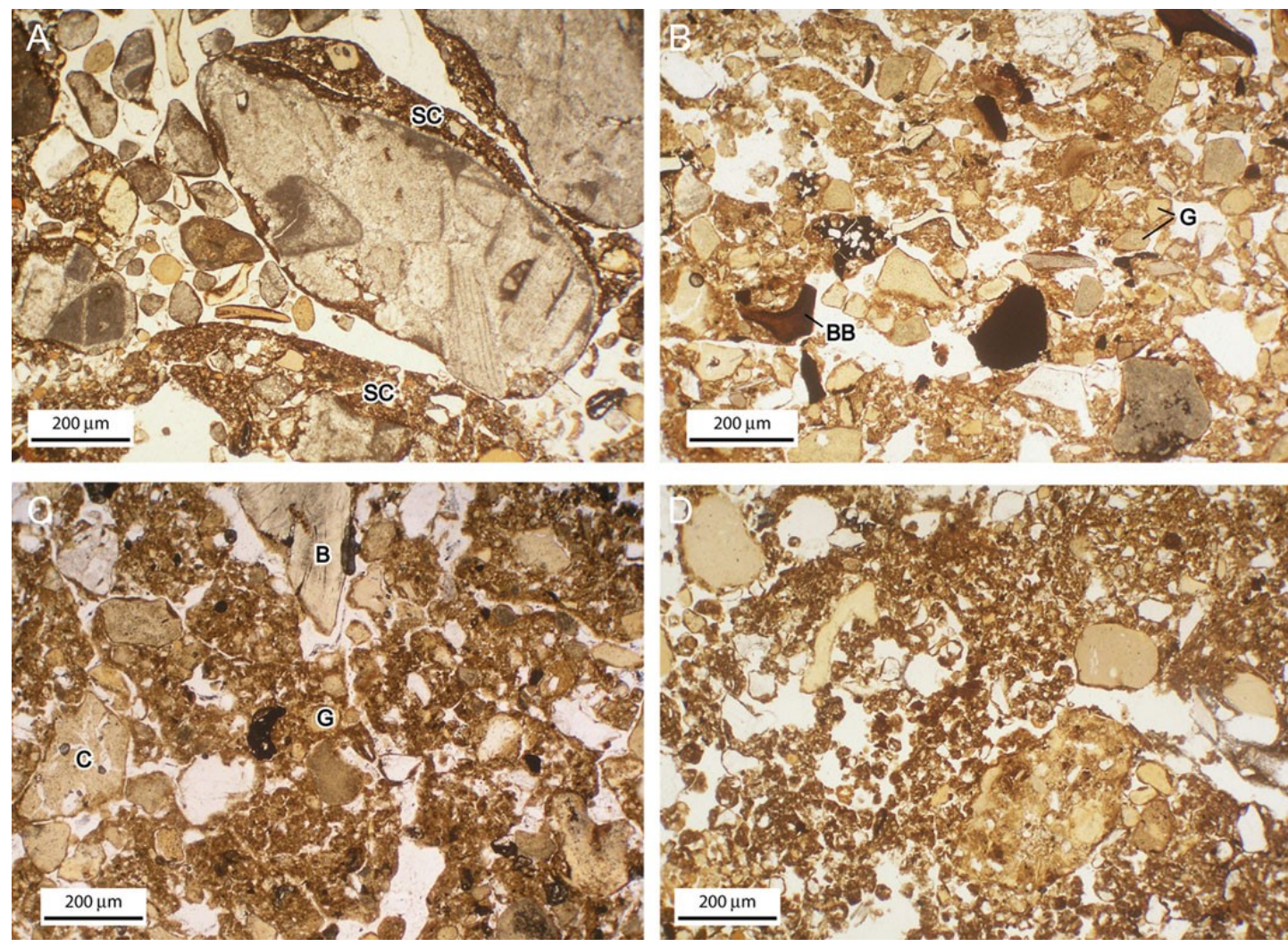

Figure $6(\mathrm{~A})$ Silt cappings (SC), layer 1, thin section, PPL; (B) platy structure (BB, burned bone fragment), layer 3, thin section, PPL; (C) bone fragment(B), phosphate nodules interpreted as precipitates derived from degraded guano (G) and coprolites (C), layer 5, thin section, PPL; (D) microaggregate structure, layer 5 , thin section, PPL.

Layer 2 (archaeological level IX): matrix-supported clastic layer composed of weathered limestone fragments and a decalcified reddish-brown (5YR 4/4) silty sand matrix, $10 \mathrm{~cm}$ thick (Figure 5B). The amount of limestone clasts provided by the fragmentation of the wall decreases significantly compared to the overlying layer. Abundant small whitish aggregates, which are likely coprolite fragments, are visible to the naked eye. The structure is platy and the coarse fragments are capped with silt accumulations. On the opposite wall of the trench, this level is overlain by a discontinuous dark brown (7.5YR 3/3) lens, which was sampled for geochemical analysis of OM (Figure 5C). Layer 2 yields both Mousterian and Chatelperronian artifacts.^

Layer 3 (archaeological levels XV to XIII): strong brown (7.5YR 5/8) homogeneous decalcified clayey sand with few weathered limestone clasts and quartz gravel cobbles (probably human imports), 15-20 cm thick. Under the microscope, a platy structure (Figure 6B) associated with thin silt cappings on the coarse elements can be observed. Phosphate nodules and bone fragments are abundant. Two types can be differentiated (Figure 6C) as follows: (1) homogeneous yellowish grains without identifiable inclusions, which are assumed to be secondary phosphate precipitations from mineralized guano (Courty et al., 1989; Macphail \& Goldberg, 1999; Bos, 2012), and (2) grayish to yellowish fragments with elongated or mammilated vughs and often small bone sherds and mineral grains, which correspond to carnivore coprolites (Horwitz \& Goldberg, 1989; Rodriguez et al., 1995). Layer 3 contains Mousterian artifacts.

Layer 4 (archaeological level XVIII): strong brown (7.5YR 4 to 5/6) clayey sand, $40 \mathrm{~cm}$ thick (Figure 5D). The coarse fraction is abundant and comprises weathered limestone blocks, some with a thin phosphate crust. Bone fragments and phosphate grains are abundant in the thin sections. The groundmass is decalcified and exhibits a dense microaggregate structure with a porosity 
composed of biogalleries, and secondary carbonate precipitations. This unit contains Mousterian artifacts.

Layer 5 (archaeological level XX): decalcified dark brown (7.5YR 3/4) clayey sands, similar to the underlying unit. In thin section, this unit displays a dense microaggregate structure with a mostly biological porosity (biogalleries; Figure 6D). Phosphate grains are abundant. This unit contains Mousterian artifacts.

Layer 6 (archaeological level XXI): decalcified dark brown (7.5YR 3/4) clayey sands, $50 \mathrm{~cm}$ thick, with few weathered limestone blocks usually reduced to pseudomorphs. Sand grains are mainly quartz. Porosity is low and composed of fissures and few biogalleries. All the limestone blocks are surrounded by a phosphatic crust that is a few centimeters thick (Figure 7A). Under the microscope, carbonates appear to be replaced by phosphates in the crusts, which preserve the original rock texture (Figure 7B). This level also contains few scattered, sand-sized yellowish dusty grains of phosphates. Thin brown to reddish brown clay coatings are present in the fissures (Figure 7C). They testify to illuviation processes following decalcification of the deposits. The brown color of the coatings suggests that OM was adsorbed on the clay particles ( $c f$. humic luvisols: Bronger, 1978; Miedema, Koulechova, \& Gerasimova, 1999). Few fragments of microlaminated light brown clay coatings were also observed (Figure 7D). They correspond to redeposited illuviated soil material, possibly from the soils surrounding the cave or from epikarstic sources. Calcite hypocoatings to voids indicate secondary calcification of the profile following burial under limestone rich detrital sediments. This unit did not yield any archaeological material.
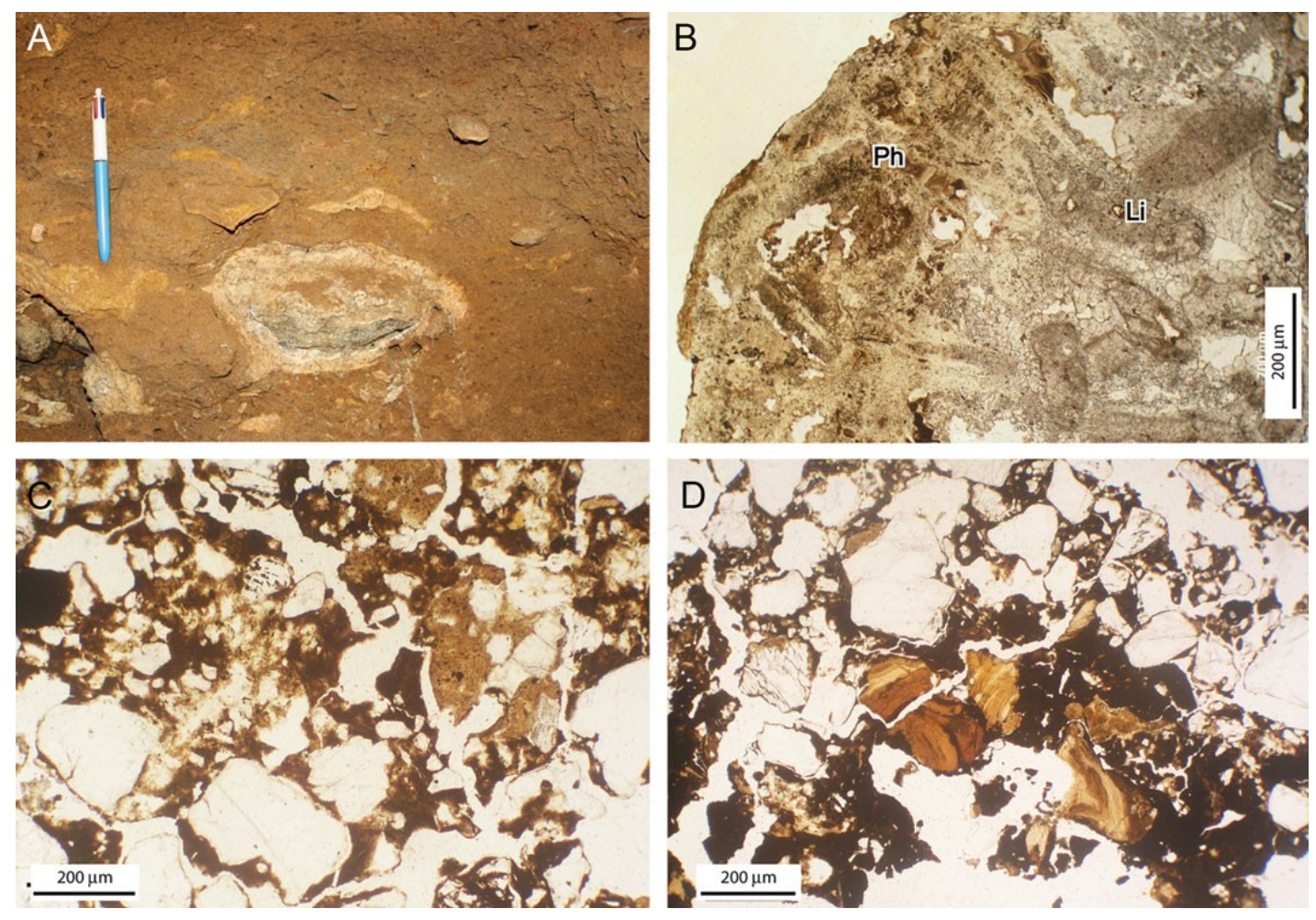

Figure 7 (A) Phosphate crust around a limestone block, layer 6. We can also distinguish completely weathered blocks reduced to pseudomorphs, which are scattered in the fine-grained residual matrix; (B) replacement of a limestone fragment by apatite- $\mathrm{CaOH}$, layer 6 , thin section, PPL; (C) brown clay coatings, layer 6 , thin section, PPL; (D) fragments of thick light yellowish clay coatings, layer 6 , thin section, PPL. 
Layer 7: strong brown (7.5YR 5/8) clayey sand with rare weathered limestone blocks, c. $10 \mathrm{~cm}$ thick. This unit is interpreted to be composed of material resulting from the weathering of limestone, brought into the cavities through the epikarstic fissures. According to Kervazo (pers. comm.), the sediments were probably redeposited by endokarstic flows since they contain siliceous fossils that are not present in the host limestone and, therefore, suggest inputs from distant karstic sources. This unit is devoid of archaeological artifacts and was not sampled, since only a very limited part was visible during our sample collection.

\section{Mineralogy}

In all the studied samples, XRD analysis revealed variable amounts of calcite, quartz, and muscovite. Quartz and muscovite come from the residual Lower Pleistocene alluvium on the plateau and accumulated in the cavity via epikarstic fissures. All the samples except for one taken in unit 1 also contain phosphates, which were determined as apatite- $\mathrm{CaOH}$ (=hydroxylapatite, $\mathrm{Ca}_{5}\left(\mathrm{PO}_{4}\right) 3(\mathrm{OH})$ ). All the phosphate nodules analyzed by Raman spectroscopy on polished plates produced a spectrum of apatite- $\mathrm{CaOH}$.

\section{TOC and Carbonates}

On average, TOC decreases toward the bottom of the sequence in connection with ageing of the deposits and subsequent mineralization of the OM (Figure 8). Significant variations in TOC, but also in $\mathrm{CaCO}_{3}$, are observed, however. Both values are inversely correlated, $\mathrm{CaCO}_{3}$ amounts decreasing while TOC increases (after correction for OM mineralization with depth). This pattern is obvious for the upper layers. According to the micromorphological analysis, the carbonates are mostly detrital in origin and come from the fragmentation of the rockwall. Overall, two lithostratigraphic units can be distinguished from the carbonate content of the matrix: layer 1 with high mean $\mathrm{CaCO}_{3}$ values ( 23 to $55 \%$ ), and layers 2-6 with a decalcified matrix $\left(\mathrm{CaCO}_{3}<9 \%\right)$.

\section{Phosphates}

Significant variations in phosphorus amounts can be seen, which follow rather closely those of TOC (Figure 8). Three peaks are identified: (1) within a darkcolored bed in layer $1(P=10 \%),(2)$ in layer 2 and at the top of layer $3(P=12 \%)$, and $(3)$ in layer $4(P=10 \%)$. According to micromorphological observations, phosphates are a mixture of coprolites, bone fragments, and precipitation derived from guano. They indicate a marked accumulation (relative to clastic sedimentation) of cave animal excrement and other $\mathrm{OM}$, as well as bone remains left by carnivores and humans. A rapid decrease in phosphate amount occurs with depth in the fine-grained matrix of the lowermost layers (layers 5 and 6), which are, in contrast, typified by abundant phosphate precipitation that form crusts around the limestone blocks. Therefore, it seems that most of the phosphates disseminated in the matrix have been remobilized in solution to form secondary accumulations on limestone fragment surfaces. These produced, like all the other types of phosphate mineralization found at Combe Sauniere, an apatite$\mathrm{CaOH}$ spectrum by XRD.

\section{Magnetic Susceptibility}

Volumetric magnetic susceptibility shows clear variations throughout the sequence (Figure 8). A first peak occurs in the Gravettian levels (layer 1 ) and reaches c. $200 \times 10^{-6} \mathrm{SI}$. Such a value is an order 
of magnitude higher than those found in non-anthropized soils on similar substrate in the region (Bertran et al., 2008) and obviously reflects heating of the sediment at relatively high temperatures $\left(>600^{\circ} \mathrm{C}\right.$, Oldfield \& Crowther, 2007). Upon heating, Fe oxides like hematite and lepidocrocite (also goethite when associated with $\mathrm{OM}$ ) convert into magnetite or maghemite, both minerals increasing the magnetic susceptibility of the sediment (Le Borgne, 1955; Rummery et al., 1979). A second peak reaching $50 \times 10^{-6} \mathrm{SI}$ is located in a brown bed in the lower part of layer 1 . Similar values are also provided by the upper part of layer 2 (Chatelperronian level) and by layers $4-6$. These ${ }^{\wedge}$ values are in agreement with those measured in the upper horizons of soils, in which bacterial activity produces small ferromagnetic particles (Mullins, 1977; Maher \& Thompson, 2009). Overall, the magnetic susceptibility is inversely correlated with the $\mathrm{CaCO}_{3}$ content of the matrix. Such a correlation between a low carbonate content, which indicates strong weathering of the sediments, and high magnetic susceptibility values speaks in favor of a pedological origin of the magnetic particles (cf. Ellwood et al., 2001). However, because of anthropization, it cannot be excluded that part of these minerals were provided by sediment heating in fireplaces and subsequent dispersal (Woodward, 1997). Accordingly, micromorphological observations show that burnt bone fragments are common throughout the sequence.

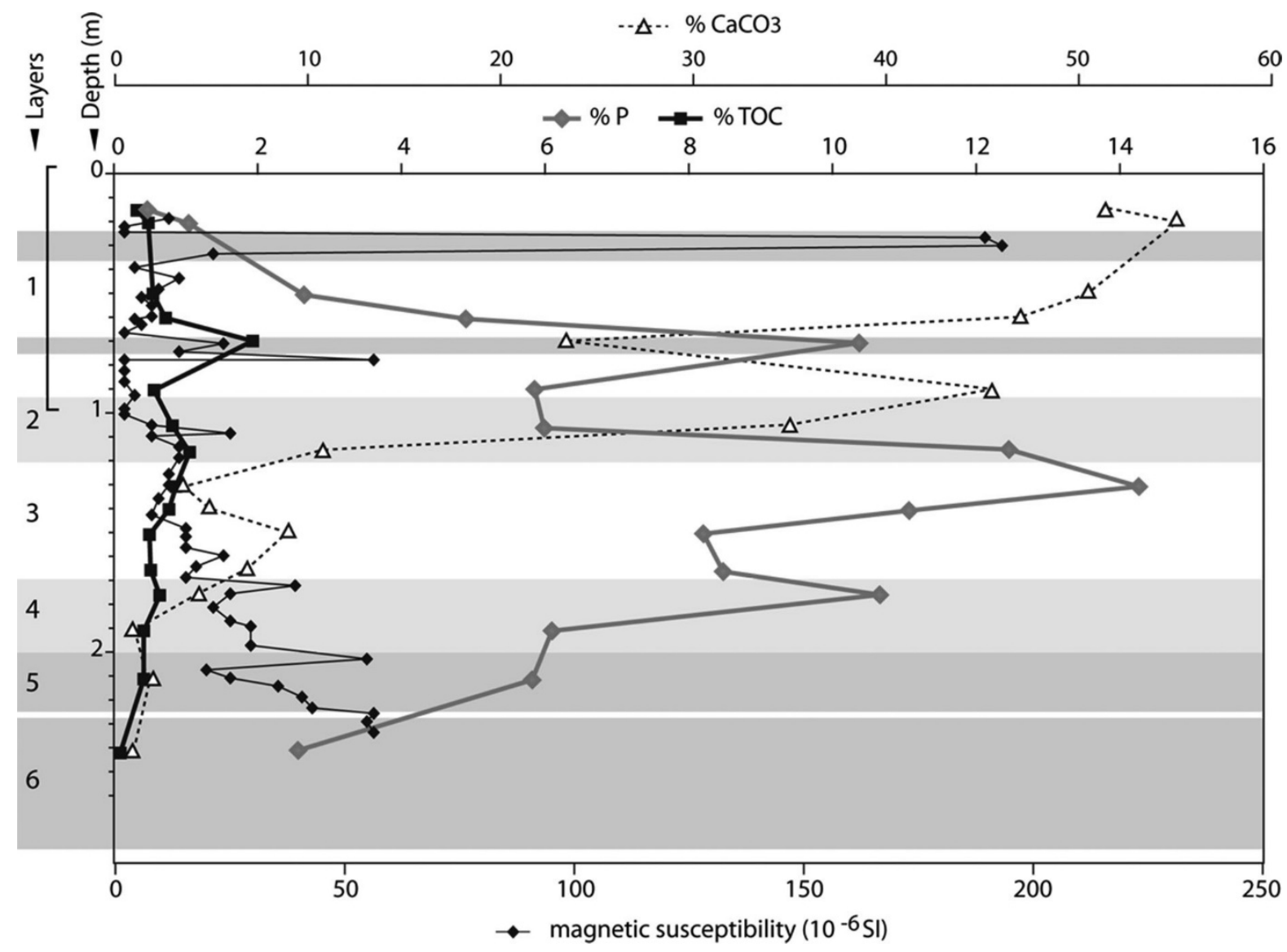

Figure 8 Stratigraphical evolution of total organic carbon, carbonates, phosphorus, and magnetic susceptibility in the Combe Sauniere sequence. 


\section{Molecular Composition of the OM}

The lipidic fraction is a complex mixture of organosoluble molecules, which often contain biomarkers of different origins. The lipidic fraction represents 104 and 107 ppm, which is very low, and signifies that fresh $\mathrm{OM}$ input is very scarce or inexistant. GC/MS analysis shows the presence of alkanes, alcohols, amides, and fatty acids. Long-chained alkanes with an odd predominance as well as long even-chained (>C20) alcohols reveal a higher plant origin (Figure 9A). The C18 alcohol (octadecanol) in high amounts in the two samples is probably of fungal origin.

Fatty acids present a bimodal distribution (Figure 9B). Among the short-chained fatty acids, the ubiquitous palmitic (C16) and stearic (C18) are predominant and associated with the unsaturated C18 (oleic acid), which derives probably from mosses (Nierop, Van Lagen, \& Buurman, 2001). These molecules are also present in lower amounts in bacteria and upper plants. The branched iso and anteiso C15 and C17 acids, which are relatively abundant compared to their linear homologues, indicate microbial activity. Long-chained fatty acid with an even-to-odd predominance is of plant origin. Amides also reflect bacteria or animal products, as they are part of proteins.

Pyrolysis and thermochemolysis products are identified in Figures 10, 11 and Tables I, II. The main pyrolysis products are long-chained alkylbenzenes, polyaromatic hydrocarbons (PAH), such as naphthalene, and phenanthrene. These compounds are of charcoal origin and are indicative of natural forest fires or anthropogenic wood fires.

Lignin moieties, such as short-chained alkylbenzens, and phenols were detected. For example, ethylphenol and methoxyphenol result from the degradation of the P-Coumaryl units of lignin. These units are ubiquitous; however, methoxyphenol is particularly abundant in the degradation products of the OM coming from conifers, and particularly from the needles (Ingemarsson et al., 1998; Nierop et al., 2001). The scarcity of molecules derived from lignin in the samples may reflect strong degradation of the functional groups and the lignin substitutes as a consequence of diagenetic processes.

Furanic compounds such as methyl and ethyl furfural originate from cellulose. They are common in the $\mathrm{OM}$ of soils that undergo a rapid turnover due to the bacterial activity. Tetramethylcyclopentadian, trimethyl, and methylcyclopentanone usually associated with mosses (Nierop, 1998) are also present.

Several amino compounds resulting from the degradation of amino acids (Poirier et al., 2005) were detected. They indicate either intense bacterial activity associated with OM humification or the presence of animal remains (soil fauna, cave fauna, as well as anthropogenic inputs of animal residues).

A series of aliphatic and olefinic hydrocarbons going from C9 to C15 are observed. These compounds could be produced from the thermal degradation of aliphatic polymers that make up the cells of microalgae.

Despite their very low amount, the organic molecules present in the samples provide a great deal of information about the origin of the organic material. The lipidic fraction reveals mostly a plant origin but contains some specific biomarkers of microbial activity, such as branched fatty acids. The complex OM recognized with the use of thermal degradation techniques is mainly composed of aromatic structures, such as lignin moieties or polyaromatic hydrocarbons. TMAH allowed us to detect alkylfurfurals originating from cellulose, and these were not observed with pyrolysis. The low amount of lipids associated with the numerous nonoxygenated aromatic compounds indicates ancient organic material. 
A
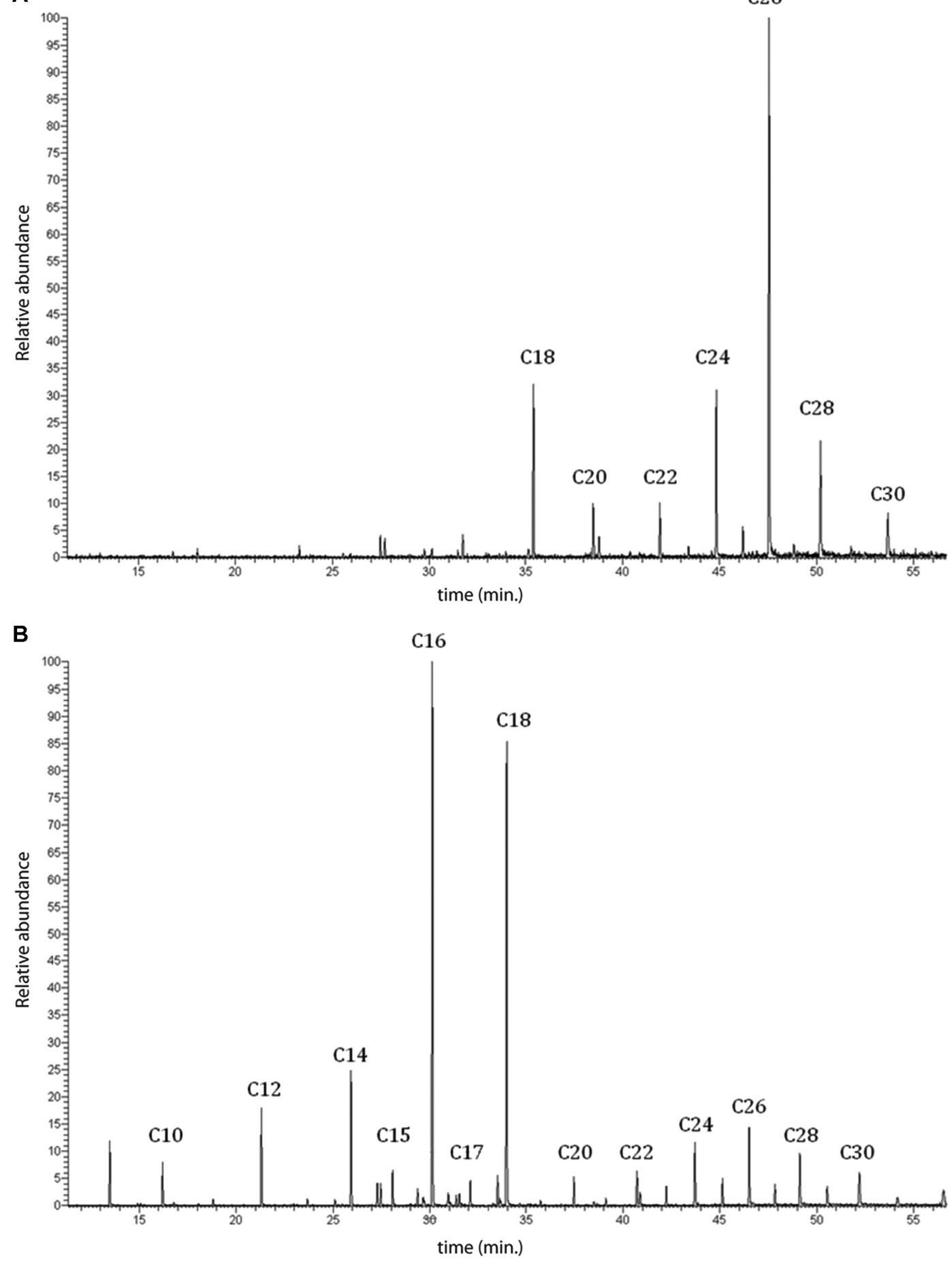

Figure 9 (A) Alcohols (acetylated) identified in the lipidic extract from sample CSO2; (B) fatty acid (methyl esters) identified in the lipid extract from sample CSO2. 


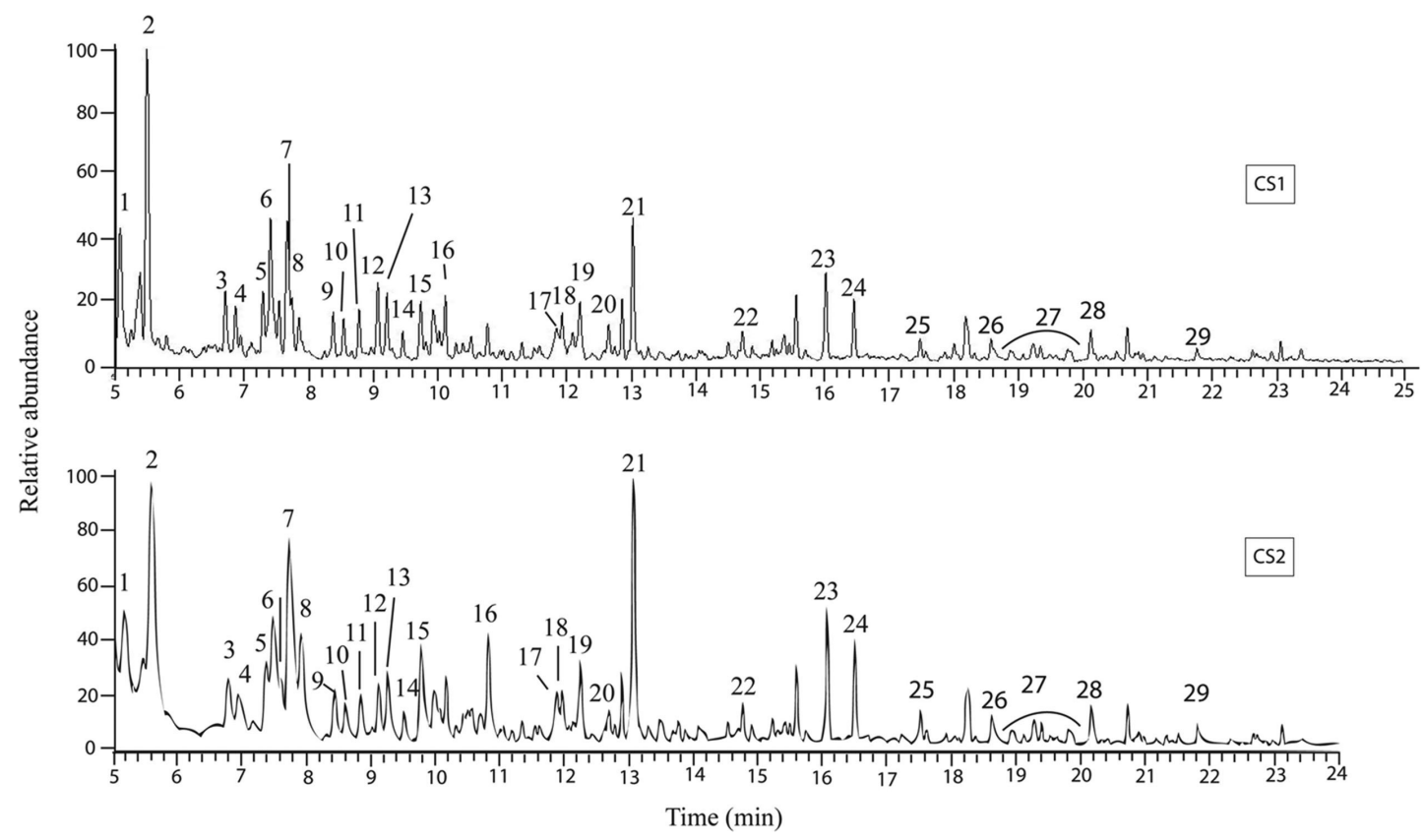

Figure 10 Pyrolysis products obtained at $600^{\circ} \mathrm{C}(\mathrm{Py}-\mathrm{GC} / \mathrm{MS})$. The numbers refer to Table I

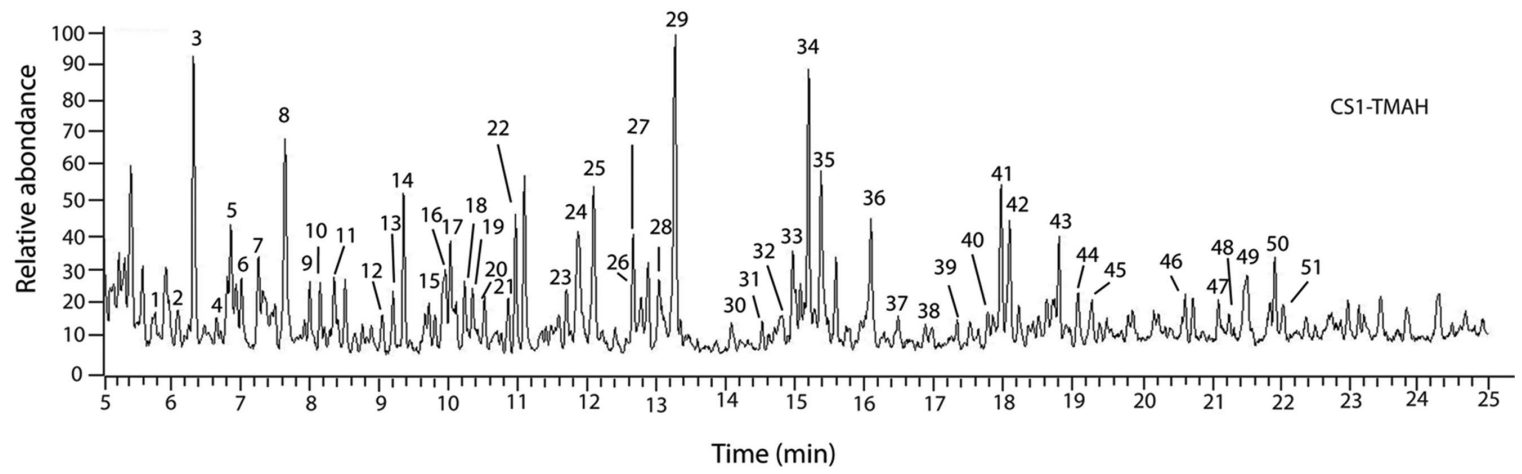

figure 11 Thermochemolysis (TMAH) products of sample CSO1. The numbers refer to Table II.

\begin{tabular}{llll}
\hline Number & \multicolumn{1}{c}{ Name } & Formula & \multicolumn{1}{c}{ Origin } \\
\hline 1 & Alkylbenzene (C2) & $\mathrm{C}_{8} \mathrm{H}_{10}$ & \multicolumn{1}{c}{ Lignin } \\
2 & Styrene & $\mathrm{C}_{8} \mathrm{H}_{5}$ & Lignin \\
3 & Alkylbenzene (C3) & $\mathrm{C}_{9} \mathrm{H}_{12}$ & Lignin \\
4 & Alkylbenzene (C3) & $\mathrm{C}_{9} \mathrm{H}_{12}$ & Lignin \\
5 & Alkylbenzene (C3) & $\mathrm{C}_{9} \mathrm{H}_{12}$ & Lignin \\
6 & Aniline & $\mathrm{C}_{6} \mathrm{H}_{7} \mathrm{~N}$ & Protein \\
7 & Bezonitrile & $\mathrm{C}_{7} \mathrm{H}_{5} \mathrm{~N}$ & Protein \\
8 & Benzofuran & $\mathrm{C}_{8} \mathrm{H}_{6} \mathrm{O}$ & Coal \\
9 & Alkylbenzene (C3) & $\mathrm{C}_{9} \mathrm{H}_{12}$ & Lignin \\
10 & Methylstyrene & $\mathrm{C}_{9} \mathrm{H}_{10}$ & Lignin \\
11 & 1H-inden. 2.3-dihydro & $\mathrm{C}_{9} \mathrm{H}_{10}$ & Coal \\
12 & 1H-inden-2.ol.2.3-dihydro- & $\mathrm{C}_{9} \mathrm{H}_{10} \mathrm{O}$ & Coal \\
13 & Alkylbenzene (C4) & $\mathrm{C}_{10} \mathrm{H}_{14}$ & Lignin \\
14 & Alkylbenzene (C4) & $\mathrm{C}_{10} \mathrm{H}_{14}$ & Lignin \\
15 & Methyl benzonitril & $\mathrm{C}_{7} \mathrm{H}_{8} \mathrm{CN}$ & Protein \\
16 & Methylbenzofuran & $\mathrm{C}_{9} \mathrm{H}_{8} \mathrm{O}$ & Coal
\end{tabular}




\begin{tabular}{llll}
17 & Alkylbenzene (C5) & $\mathrm{C}_{11} \mathrm{H}_{16}$ & Lignin \\
18 & Alkylbenzene (C4) & $\mathrm{C}_{10} \mathrm{H}_{14}$ & Lignin \\
19 & Alkylbenzene (C5) & $\mathrm{C}_{11} \mathrm{H}_{16}$ & Lignin \\
20 & Naphthalene & $\mathrm{C}_{10} \mathrm{H}_{8}$ & Coal \\
21 & 1Methylene- $1 \mathrm{H}$-indene & $\mathrm{C}_{10} \mathrm{H}_{8}$ & Coal \\
22 & B-Methylnaphthalene & $\mathrm{C}_{11} \mathrm{H}_{10}$ & Coal \\
23 & Methylnaphthalene & $\mathrm{C}_{11} \mathrm{H}_{10}$ & Coal \\
24 & Methylnaphthalene & $\mathrm{C}_{11} \mathrm{H}_{10}$ & Coal \\
25 & Alkylbenzene (C7) & $\mathrm{C}_{12} \mathrm{H}_{10}$ & Coal \\
26 & Ethylnaphtalene & $\mathrm{C}_{12} \mathrm{H}_{12}$ & Coal \\
27 & Dibenzofuran & $\mathrm{C}_{11} \mathrm{H}_{8} \mathrm{~N}_{2}$ & Coal \\
28 & Phenanthrene & $\mathrm{C}_{14} \mathrm{H}_{10}$ & Coal \\
\hline \multicolumn{4}{r}{ Table I List of the products obtained by pyrolysis at $600^{\circ} \mathrm{C}}$.
\end{tabular}

\begin{tabular}{|c|c|c|c|}
\hline Number & Name & Formula & Origin \\
\hline 1 & Methyltetrahydrofuran & $\mathrm{C}_{6} \mathrm{H}_{8} \mathrm{O}$ & Cellulose \\
\hline 2 & Ethylphenol & $\mathrm{C}_{8} \mathrm{H}_{10} \mathrm{O}$ & Lignin \\
\hline 3 & Methylfurfural & $\mathrm{C}_{6} \mathrm{H}_{8} \mathrm{O}$ & Cellulose \\
\hline 4 & Alkylbenzene (C3) & $\mathrm{C}_{9} \mathrm{H}_{12}$ & Lignin \\
\hline 5 & Tetramethylcyclopentadien & $\mathrm{C}_{9} \mathrm{H}_{14}$ & Lignin \\
\hline 6 & Alkylbenzene (C3) & $\mathrm{C}_{9} \mathrm{H}_{12}$ & Lignin \\
\hline 7 & Alkylbenzene (C3) & $\mathrm{C}_{9} \mathrm{H}_{12}$ & Lignin \\
\hline 8 & Alkylbenzene (C3) & $\mathrm{C}_{9} \mathrm{H}_{12}$ & Lignin \\
\hline 9 & Pentamethylcyclopentadiene & $\mathrm{C}_{10} \mathrm{H}_{16}$ & Lignin \\
\hline 10 & $1 \mathrm{H}$-trimethylpyrrole & $\mathrm{C}_{7} \mathrm{H}_{11} \mathrm{~N}$ & Protein \\
\hline 11 & Alkylbenzene (C3) & $\mathrm{C}_{9} \mathrm{H}_{12}$ & Lignin \\
\hline 12 & Indene & $\mathrm{C}_{9} \mathrm{H}_{8}$ & Coal \\
\hline 13 & Alkylbenzene (C4) & $\mathrm{C}_{10} \mathrm{H}_{14}$ & Lignin \\
\hline 14 & Ethylfurfural & $\mathrm{C}_{8} \mathrm{H}_{12} \mathrm{O}$ & Cellulose \\
\hline 15 & Alkylbenzene (C4) & $\mathrm{C}_{10} \mathrm{H}_{14}$ & Lignin \\
\hline 16 & Ethenyl-dimethylbenzene & $\mathrm{C}_{10} \mathrm{H}_{12}$ & Lignin \\
\hline 17 & Tetramethylpyrrole & $\mathrm{C}_{8} \mathrm{H}_{13} \mathrm{~N}$ & Protein \\
\hline 18 & Dimethylaniline & $\mathrm{C}_{8} \mathrm{H}_{11} \mathrm{~N}$ & Protein \\
\hline 19 & Alkylbenzene (C4) & $\mathrm{C}_{10} \mathrm{H}_{14}$ & Lignin \\
\hline 20 & Alkylbenzene (C4) & $\mathrm{C}_{10} \mathrm{H}_{14}$ & Lignin \\
\hline 21 & Alkylbenzene (C4) & $\mathrm{C}_{10} \mathrm{H}_{14}$ & Lignin \\
\hline 22 & Alkylbenzene (C4) & $\mathrm{C}_{10} \mathrm{H}_{14}$ & Lignin \\
\hline 23 & 4-Methoxy-3-methylphenol \# & $\mathrm{C}_{8} \mathrm{H}_{10} \mathrm{O}_{2}$ & Lignin \\
\hline 24 & Alkylbenzene (C4) & $\mathrm{C}_{10} \mathrm{H}_{14}$ & Lignin \\
\hline 25 & Methylindene & $\mathrm{C}_{10} \mathrm{H}_{10}$ & Coal \\
\hline 26 & Methylene-butenylbenzene & $\mathrm{C}_{11} \mathrm{H}_{12}$ & Lignin \\
\hline 27 & Methyltetralin & $\mathrm{C}_{11} \mathrm{H}_{14}$ & Coal \\
\hline 28 & Azulene & $\mathrm{C}_{10} \mathrm{H}_{8}$ & Coal \\
\hline 29 & Dimethylaminophenol & $\mathrm{C}_{8} \mathrm{H}_{11} \mathrm{NO}$ & Lignin \\
\hline 30 & Dimethylcumene & $\mathrm{C}_{11} \mathrm{H}_{16}$ & Lignin \\
\hline 31 & 3-Ethylamino-4-methylphenol & $\mathrm{C}_{9} \mathrm{H}_{13} \mathrm{NO}$ & Protein \\
\hline 32 & Dimethylindene & $\mathrm{C}_{11} \mathrm{H}_{12}$ & Coal \\
\hline 33 & Dimethylindene & $\mathrm{C}_{11} \mathrm{H}_{12}$ & Coal \\
\hline 34 & Dimethylindene & $\mathrm{C}_{11} \mathrm{H}_{12}$ & Coal \\
\hline 35 & Alkylbenzene(C5) & $\mathrm{C}_{11} \mathrm{H}_{16}$ & Lignin \\
\hline 36 & Methylnaphthalene & $\mathrm{C}_{11} \mathrm{H}_{10}$ & Coal \\
\hline 37 & Methylnaphthalene & $\mathrm{C}_{11} \mathrm{H}_{10}$ & Coal \\
\hline 38 & Methylnaphthalene & $\mathrm{C}_{11} \mathrm{H}_{10}$ & Coal \\
\hline 39 & Hexamethylbenzene & $\mathrm{C}_{12} \mathrm{H}_{18}$ & Lignin \\
\hline 40 & Dimethylindole & $\mathrm{C}_{10} \mathrm{H}_{11} \mathrm{~N}$ & Protein \\
\hline 41 & Trimethylindene & $\mathrm{C}_{12} \mathrm{H}_{14}$ & Coal \\
\hline 42 & Trimethylindene & $\mathrm{C}_{12} \mathrm{H}_{14}$ & Coal \\
\hline
\end{tabular}




\begin{tabular}{llll}
43 & Ethylnaphthalene & $\mathrm{C}_{12} \mathrm{H}_{12}$ & Coal \\
44 & Ethylnaphthalene & $\mathrm{C}_{12} \mathrm{H}_{12}$ & Coal \\
45 & Ethylnaphthalene & $\mathrm{C}_{12} \mathrm{H}_{12}$ & Coal \\
46 & Ethylnaphthalene & $\mathrm{C}_{12} \mathrm{H}_{12}$ & Coal \\
47 & Dimethylindole & $\mathrm{C}_{10} \mathrm{H}_{11} \mathrm{~N}$ & Protein \\
48 & Ethylnaphthalene & $\mathrm{C}_{12} \mathrm{H}_{12}$ & Coal \\
49 & Trimethylnaphthalene & $\mathrm{C}_{13} \mathrm{H}_{14}$ & Coal \\
50 & Trimethylindole & $\mathrm{C}_{11} \mathrm{H}_{13} \mathrm{~N}$ & Protein \\
51 & Trimethylnaphthalene & $\mathrm{C}_{13} \mathrm{H}_{14}$ & Coal \\
\hline
\end{tabular}

Table II List of the products obtained by thermochemolysis (TMAH).

As for many other cave sites, a strong scatter of the dates is observed within each level. For $14 \mathrm{C}$ ages, this is most likely due to the incomplete elimination of organic contamination during sample processing, and recent AMS dates on ultrafiltered extracts of collagen typically produced ages a few thousand years older than those previously obtained from the same levels (Higham, Jacobi, \& Bronk Ramsey, 2006; Mellars, 2006). Taphonomic factors may also be involved and a plausible alternative to age rejuvenation could be the admixture of younger charcoal pieces into the levels via cryoturbation. Accordingly, many dates appear to be younger than expected with respect to their associated technocomplex when they are critically compared to existing Palaeolithic radiocarbon databases (Djindjian, 1998; d'Errico et al., 2011, Joris et al., 2011) and" recent series of AMS ages on purified collagen (Higham et al., 2011). The more ancient ages should be regarded as the most reliable for the Solutrean Gravettian, Aurignacian, and Chatelperronian levels.

Two dates are older than expected for the Magdalenian level and are likely the result of taphonomic factors.

Only two ESR dates are available for the lower part of the sequence, which is older than 60 ka and, thus, beyond the range of radiocarbon methods. We assume these dates to be valid.

The obtained age model shows a gradual increase in the sedimentation rate through time. This rate remains low between 84 and $\sim 40 \mathrm{ka}$, then increases quickly. The poor resolution of the model does not allow for the identification of possible plateaus due to cessation of sedimentation and erosional phases or, to the contrary, of rapid rate increases with duration shorter than a few millennia.

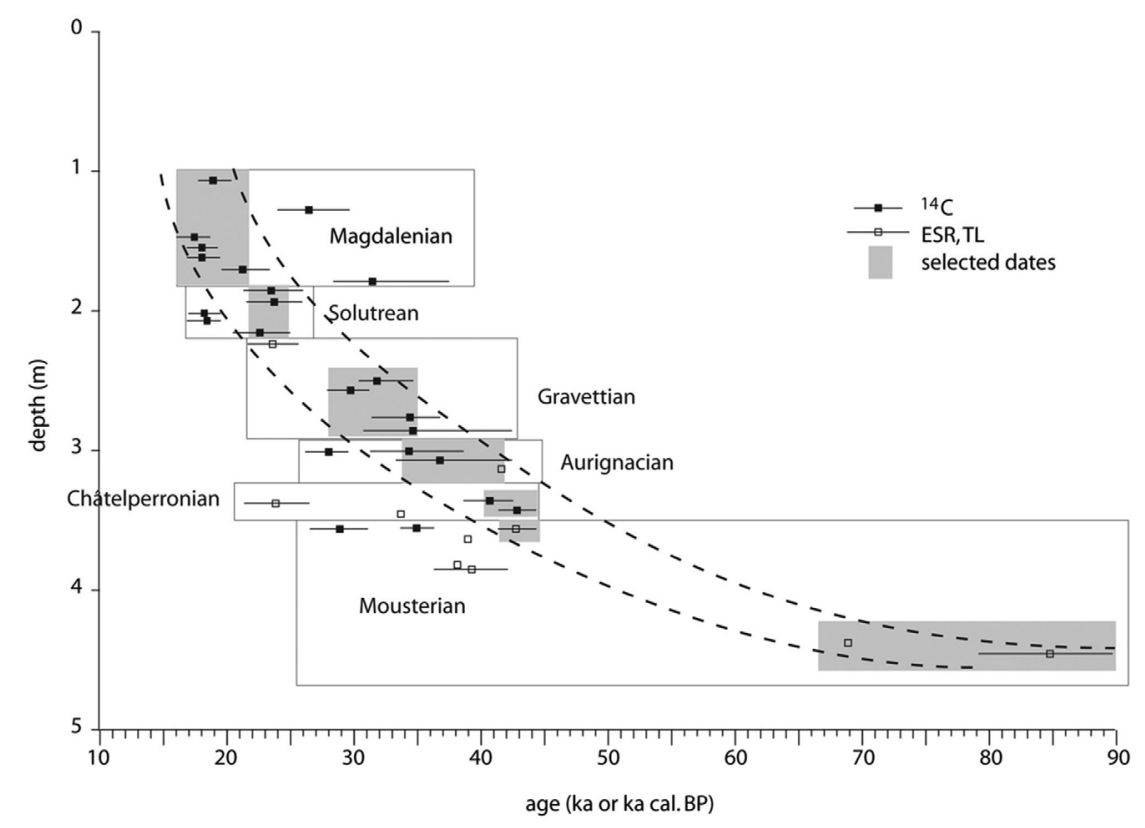

Figure 12 Age model of the Combe Sauniere sequence. Radiocarbon dates have been calibrated using the IntCal09 curve (Reimer et al., 2009). 


\section{DISCUSSION}

With the exception of the lowermost layer (L. 7), the whole Combe Sauniere sequence is interpreted as a rock-' fall talus that developed at the cave entrance following the opening of the karst conduit and subsequent wall fragmentation. Because of intense epigenetic modification due to weathering and freeze-thaw cycles (cryoturbation), the original sedimentary features are poorly preserved, and sedimentary processes other than rockfall involved in detrital accumulation remain difficult to identify. The weathering intensity documented by the analyses highlights a bipartition of the sequence. The upper unit (L. 1), which was deposited during the Aurignacian and Gravettian periods, is typified by an overall weak alteration as shown by the calcareous matrix, and predominant periglacial pedofeatures (platy structure due to ice lensing, silt cappings; Van Vliet-Lanoe, 2011). The intercalated cryoturbated dark" brown beds are characterized by the accumulation of both OM and phosphates coming from cave animal excrement and from bones, by an increase in magnetic susceptibility due to the bacterial activity and/or the anthropization, and by a decrease in the $\mathrm{CaCO}_{3}$ content of the matrix in connection with a moderate alteration. The phosphates show little evidence of leaching and transformation. According to the observations of Shahack-Gross et al. (2004) and Bos (2012), phosphate precipitates similar in morphology to those found at Combe Sauniere form quickly in decomposing guanos. 'In the modern examples investigated by Bos (2012), which contained humified but still recognizable organic (mainly insect) remains, the authigenic phosphate minerals were brushite $\left(\mathrm{Ca}\left(\mathrm{PO}_{3} \mathrm{O}\right) \cdot 2 \mathrm{H}_{2} \mathrm{O}\right)$, francoannellite $\left(\mathrm{K}_{3} \mathrm{Al}_{5}\left(\mathrm{PO}_{3} \mathrm{OH}\right)_{6}\left(\mathrm{PO}_{4}\right)_{2} .12 \mathrm{H}_{2} \mathrm{O}\right)$, and taranakite $\left(\mathrm{K}_{3} \mathrm{Al}_{5}\left(\mathrm{PO}_{3} \mathrm{OH}\right)_{6}\left(\mathrm{PO}_{4}\right)_{2} .18 \mathrm{H}_{2} \mathrm{O}\right)$, usually associated with gypsum, while apatite- $\mathrm{CaOH}$ remained in low amounts. It is likely that the replacement of these phosphate minerals by apatite- $\mathrm{CaOH}$ occurred due to the influence of calcium-rich percolating water.

We interpret these dark brown levels as buried humic horizons (cf. (humic) leptosols, FAO-WRB, 2006) that were anthropized (i.e., part of their components was derived from human activities) to variable degrees. They testify to a temporary cessation or at least to an important decrease in clastic sedimentation on the talus. Similar soils with a Ah-C profile have been described in rockshelters and cave entrances in the modern alpine and periglacial altitudinal belts of the Pyrenees (Bertran et al., 2009; Figure $13 \mathrm{~A}$ and $\mathrm{B}$ ). In these contexts, the OM comes both from the herbaceous vegetation that develops on the talus and from the introduction of organic debris by wind and biological activity (mammals, birds). Soil decalcification due to the acidification of the percolating water $\left(\mathrm{CO}_{2}\right.$ and dissolved organic acids produced by the vegetation and the degradation of excrements) remains limited because of continual inputs of limestone debris provided by the frost-induced degradation of the rockwall. In the soils, the moisture due to runoff along the wall and snow melt favors melanization of the $\mathrm{OM}$ and the development of dark Ah horizons. Charcoal dust from human activities may have also contributed to the dark color. 

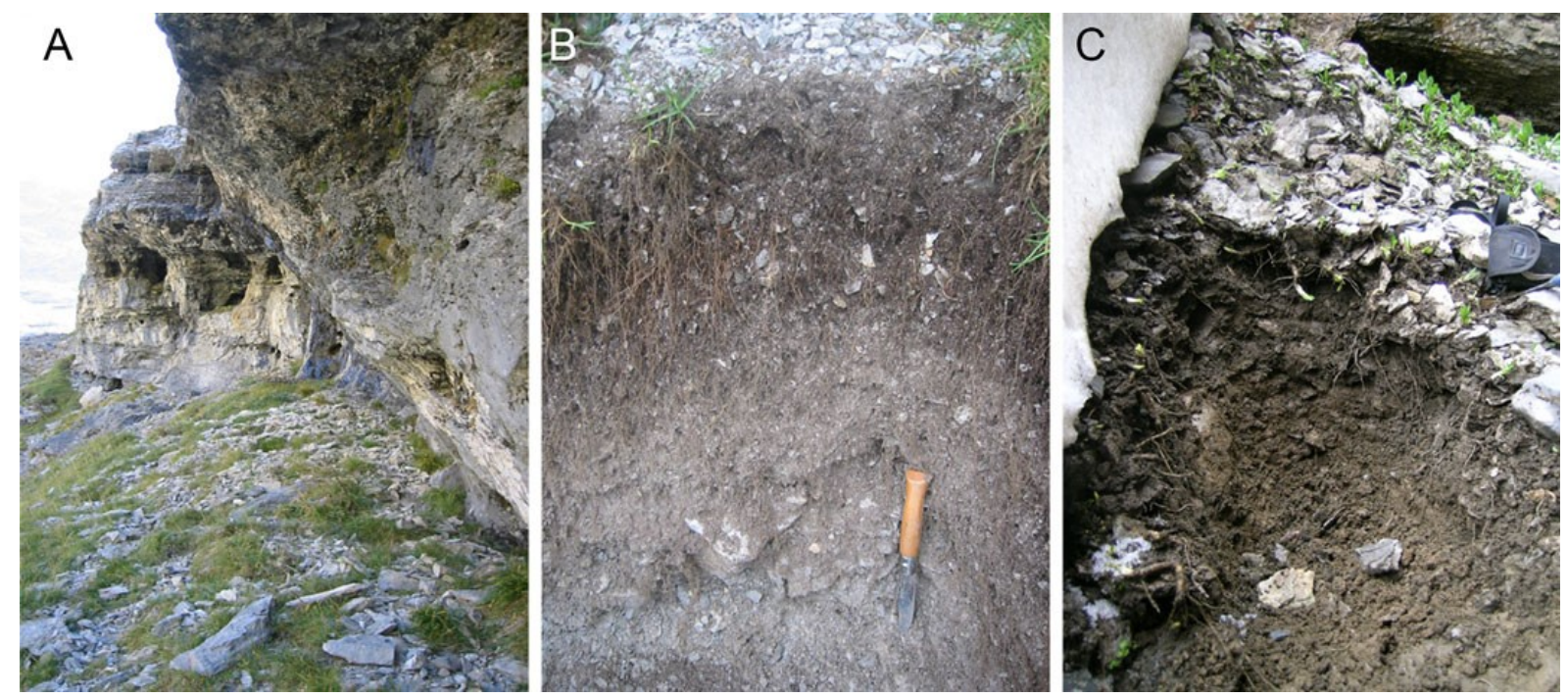

Figure 13 (A) Rockshelter in the Vallon d'Estaube, French Pyrenees,' c. $1900 \mathrm{~m}$ altitude. The rockwall produces little debris and the ground is partially colonized by alpine grass, which forms solifluction steps on the slope; (B) leptosol in a

rockshelter, French Pyrenees, $2800 \mathrm{~m}$ altitude. The soil profile is composed of a simple fluffy humic horizon rich in limestone fragments. At the surface, the fragments undergo rapid creep due to freeze-thaw cycles; (C) profile of a cambisol developed at a cave entrance, French Pyrenees, $2300 \mathrm{~m}$ altitude. The Ah horizon is dark-colored because of hydromorphy due to the presence of a small fern subsisting until the middle of July. This horizon is overlain by a stone pavement. The stones have well-developed silt cappings in the B-horizon

The lower part of the sequence (L. 2 to 6) underwent stronger weathering than layer 1 . The limestone clasts are scattered within a residual brown to reddish brown clayey matrix, which yields high magnetic susceptibility values. Three soils typified by a (Ah)-B/BTh profile can be distinguished. The first developed in layers $5-6$ in the basal part of the sequence, the second in layer 4 , and the last in layers 2-3. The palaeosols in layers 2-3 (Chatelperronian-Mousterian) and layer 4 (Mousterian) approximate a phosphatized cambic B-horizon with stronger decalcification than in layer 1. Layers 23 has been deformed by periglacial processes and exhibits a platy structure due to ice lensing, whereas layer 4 has a microaggregate structure similar to that described for desaturated cambic horizons (Aurousseau, Curmi, \& Bresson, 1985). The Chatelperronian Ah horizon has^ only been locally preserved. The $\mathrm{OM}$ extracted from this horizon has a dominantly vegetal origin and comes from the degradation of vascular plants with a probable contribution of conifers, along with mosses and bacteria. Such a composition suggests a partially forested environment with abundant mosses, which probably developed on the internal, shaded slope of the talus and on the rockwall. Modern soil analogs are found in rockshelters and caves in alpine and subalpine (forested) milieus of the Pyrenees, which have been deglaciated since the Lateglacial or the beginning of the Holocene (Figure 13C).

In the lower palaeosol (layers 5-6), the limestone fragments are almost completely altered and only a few large blocks with a thick phosphate crust are present. Although colluviation of older soil or karstic material may have contributed to the formation of the decalcified clayey matrix, there is strong evidence of in situ weathering, suggesting that most of the field characteristics of layers 5-6 are not inherited from older sources but result from pedological processes at the cave entrance. Humic illuviation took place (BTh) and indicates long-term soil leaching and stable physicochemical conditions. Simultaneously, large quantities of phosphates that accumulated due to the activities of cave animals were dissolved and reprecipitated within the soil profile. According to the stability diagram of the phosphate phases in the Ca-P-Al-K system proposed by Karkanas et al. (2000), the exclusive presence of apatite- $\mathrm{CaOH}$ suggests that a basic to neutral $\mathrm{pH}$ prevailed in the BTh horizon. However, as previously mentioned, replacement of phosphate minerals may have occurred upon postdepositional evolution and may explain why apatite- $\mathrm{CaOH}$ is the predominant phase identified in the 
deposits, in contrast to recent guanos. No modern analogs of this soil have been documented in caves within the region. This may be due to intense modifications that occurred during the Neolithic and medieval periods, which were characterized by widespread cave occupation by people and cattle, thus, limiting the development of a "normal" soil profile. For instance, more than $2 \mathrm{~m}$ of humic anthropogenic deposits accumulated at Combe Sauniere during the Holocene.

Despite the uncertainties associated with the dating of the archaeological levels, the proposed age model unambiguously indicates an increase in sedimentation rate through time. Consequently, the identified palaeosols should be considered in a preliminary approximation as a time-dependant sequence of soil development within cave entrance settings. Within layer 1 , the palaeosols correspond to simple humic horizons (leptosols) that evolved over short time spans. Similar humic horizons have been reported at La Ferrassie by Bertran et al. (2008) and were thought to reflect millenniumlong DO interstadials at the end of MIS 3 and during MIS 2 (Svensson et al., 2005). The palaeosols that developed in layers 2-3 and 4 have a phosphate-rich cambic Bhorizon and may be classified as phosphatized (chromic) cambisols. In layer 4, some of the phosphates form crusts around limestone blocks. These soils share common features with ornithogenic soils in penguin rockeries of the southern hemisphere (Simas et al., 2007), and reflect a longer, possibly plurimillennial period of low or null clastic sedimentation and of, conversely, strong weathering. The available chronological data suggest that the palaeosol in layers 2-3 corresponds to the beginning of MIS 3, whereas that in layer 4 represents the Early Glacial (the end of MIS 5 to the beginning of MIS 4).

The soil in layers 5-6, which exhibits an illuvial BTh horizon (phosphatized humic luvisol), reflects an ultimate stage of the pedological evolution and should have an interglacial (sensu lato) rank. The ESR date of $84.4 \pm 5.3$ ka obtained on a bone fragment at the base of layer 4 gives an end limit for its formation. This kind of soil is assumed to be typical of caves (e.g., Jenkins, 1994). In open-air settings in limestone debris, the luvisol stage is seldom reached during the Holocene because the Bhorizon remains Ca-saturated, thus, limiting illuviation. Guano accumulation in caves is likely the key factor that explains the development of luvisols on initially highly calcareous materials. Guano leads to acidification of the percolating water (Martini \& Kavalieris, 1978; Karkanas et al., 2000) and induces rapid dissolution of carbonates and soil desaturation.

\section{CONCLUSION}

The analysis of the Combe-Sauniere sequence, which is representative of many other cave entrance sequences in southwest France spanning the last climatic cycle, shows that (anthropized) palaeosols developed during periods of low clastic sedimentation at the same time as the accumulation of OM and phosphates by cave animals. During the end of MIS 3 (Aurignacian and Gravettian levels), the palaeosols can be classified as cryoturbated leptosols and may have formed in connection with short-duration mild phases. At the beginning of MIS 3 (Mousterian and Chatelperronian levels), a phosphatized cambic B-^ horizon formed and may reflect a longer period of pedological modification. This soil has been strongly affected by cryoturbation. The Last Interglacial to Early Glacial levels are typified by the development of a phosphatized humic luvisol, followed by a phosphatized cambisol. Although the poor chronological resolution prevents clear conclusions to be drawn concerning the respective role of the factors involved, phosphate accumulation and subsequent sediment alteration do not seem to be controlled by the absence of human occupation as previously proposed by Courty et al. (1989) and Karkanas et al. (2002), but rather by the duration of the soil-forming periods. This study also suggests that, although cave and rockshelter configuration plays a significant role in sedimentation (Woodward \& Goldberg, 2001), the sequences record a regional climatic signal that obviously explains the overall similarity of many of them in southwest France. Further studies of the region's cave sequences will allow for the construction and refinement of a new chronostratigraphic 
framework for these deposits, thereby allowing us to better understand the associated Palaeolithic occupations.

We gratefully acknowledge J.M. Geneste (CNP, Perigueux)' and J.P. Chadelle (CG 24, Perigueux) who excavated Combe' Sauniere for providing us unpublished data and for a critical re-'view of the manuscript, $\mathrm{H}$. Etcheber (EPOC, Talence) for the $\mathrm{TOC}^{-}$and $\mathrm{CaCO}{ }_{3}$ analyses, and E. Lebraud (ICMCB, Talence) for the XRD analyses. B. Kervazo (CNP, Perigueux) for his constructive' remarks on the manuscript and W. Banks for editing the English are also acknowledged. The editor of the journal, J. Woodward, and two anonymous reviewers have significantly contributed to improving the original manuscript.

\section{REFERENCES}

Ali, S.A., Clark, W.J., Moore, W.R., \& Dribus, J.R. (2010). Diagenesis and reservoir quality. Oilfield Review, 22(2), 14-27.

Aurousseau, P., Curmi, P., \& Bresson, L.M. (1985). Microscopy of the Cambic Horizon. Soil Micromorphology and Soil Classification. Soil Science Society of America, Madison, 49-62.

Bertran, P., Courbouleix, S., Clement, B., Coussot, P.,'Coutard, J.P., Fabre, R., Francou, B., Hetu, B., Jomelli, V.,' Le Bissonnais, V., Meunier, M., \& Texier, J.P. (2004). Dep' ots de pente continentaux. Dynamique et facies. 'Quaternaire, hors-série 1 (258 p.)'

Bertran, P., Caner, L., Langohr, R., Lemee, L., \& D'Errico, F.'(2008). Continental palaeoenvironments during MIS 2 and 3 in southwestern France: The La Ferrassie rockshelter record. Quaternary Science Reviews, 27, 2048-2063.

Bertran, P., Beauval, C., Boulogne, S., Brenet, M., Chzravzez,J., Claud, E., Costamagno, S., Laroulandie, V., Lenoble, A.,Malaurent, P., Masson, B., Mallye, J.B., Sin, P., Thiebaut,' C., \& Vallin, L. (2009). Dynamique sédimentaire et' taphonomie des abris sous roche et des porches de grotte en milieu périglaciaire: le programme GAVARNIE.' Nouvelles de l'Archéologie, 118, 11-16.'

Bertran, P., Klaric, L., Lenoble, A., Masson, B., \& Vallin, L. (2010). The impact of periglacial processes on Palaeolithic sites: The case of sorted patterned grounds. Quaternary International, 214, 17-29.

Blair, T.C., \& McPherson, J.G. (1994). Alluvial fans and their natural distinction from rivers based on morphology, hydraulic processes, sedimentary processes, and facies assemblages. Journal of Sedimentary Research, A64(3), 450-489.

Bos, T. (2012). Dynamiques d'accumulation des phosphates en milieu karstique (79 p.). Master's dissertation in Prehistory, University Bordeaux 1, France.

Bronger, A. (1978). Climatic sequences of steppe soils from Eastern Europe and the USA with emphasis on the genesis of the 'argillic horizon'. Catena, 5, 33-51.

Bull, P.A., \& Goldberg, P. (1985). Scanning electron microscope analysis of sediments from Tabun Cave, Mount Carmel, Israel. Journal of Archaeological Science, 12, 177-185.

Bullock, P., Fedoroff, N., Jongerius, A., Stoops, G., Tursina, T.,' \& Babel, U. (1985). Handbook for soil thin section description. Wolverhampton: Waine Research Publications. 
Courty, M.A., \& Vallverdu, J. (2001). The microstratigraphic record of abrupt climate changes in cave sediments of the Western Mediterranean. Geoarchaeology: An International Journal, 16(5), 467500.

Courty, M.A., Goldberg, P., \& Macphail, R.I. (1989). Soils and micromorphology in archaeology. Cambridge: Cambridge University Press.

D’Errico, F., Banks, W., Vanhaeren, M., Laroulandie, V., \& Langlais, M. (2011). PACEA geo-referenced radiocarbon database. PaleoAnthropology, 1-12. doi:10.4207/PA.2011.ART40.

De Sonneville-Bordes, D. (1958). Recherches sur le Paléolithique supérieur en Périgord. Université de' Bordeaux 1, France.

Djindjian, F. (1998). Datations 14C du Paleolithique supérieur' européen: bilan et perspectives. In J. Evin, C. Oberlin, J.P.' Daugas, \& J.F. Salles (Eds.), 14C et Archéologie' (pp. 171-179). Rennes, France: Mémoire de la Société' Préhistorique Française, XXVI.

Downs, R.T. (2006). The RRUFF Project: An integrated study of the chemistry, crystallography, Raman and infrared spectroscopy of minerals. Program and Abstracts of the 19th General Meeting of the International Mineralogical Association in Kobe, Japan, 003-13.

Ellwood, B.B., Harrold, F.B., Benoist, S.L., Strauss, L.G.,Morales, M.G., Petruso, K., Bicho, N.F., Zilhao, J., \& Soler, $\sim$ N. (2001). Paleoclimate and intersite correlations from Late Pleistocene/Holocene cave sites: Results from southern Europe. Geoarchaeology: An International Journal, 16(4), 433-463.

FAO-WRB. (2006). World Reference Base for Soil Resources 2006. World Soil Resources report 103, Rome: Food and Agriculture Organization of the United Nations.

Geneste, J.M., \& Chadelle, J.P. (1996). Combe Sauniere.' Rapport d'operation (600 p.). Unpublished report, Service' regional de l'Arch' eologie d'Aquitaine, Bordeaux, France.'

Goldberg, P. (1979). Micromorphology of Pech-de-l'Aze II' sediments. Journal of Archaeological Science, 6, 17-47.

Goldberg, P., \& Sherwood, S.C. (2006). Deciphering human prehistory through the geoarchaeological study of cave sediments. Evolutionary Anthropology, 15, 20-36.

Guillore, P. (1980). Méthode de fabrication mécanique et en' série des lames minces. Unpublished report, Institut' National d'Agronomie Paris-Grignon.

Higham, T.F.G., Jacobi, R.M., \& Bronk Ramsey, C. (2006). AMS radiocarbon dating of ancient bone using ultrafiltration. Radiocarbon, 48(2), 179-195.

Higham, T., Jacobi, R., Basell, L., Bronk Ramsey, C., Chiotti, L., \& Nespoulet, R. (2011). Precision dating of the Palaeolithic: A new radiocarbon chronology for the Abri Pataud (France), a key Aurignacian sequence. Journal of Human Evolution, 61, 549-563.

Horwitz, L.K., \& Goldberg, P. (1989). A study of Pleistocene and Holocene hyena coprolites. Journal of Archaeological Science, 16, 71-94. 
IMA. (2009). List of mineral names. http://pubsites.uws.edu. au/ima-cnmnc/IMA200901UPDATE160309.pdf.

Ingemarsson, A., Nilsson, U., Nilsson, M., Pedersen, J.R., \& Olsson, J. (1998). Slow pyrolysis of spruce and pine samples studied with GC/MS and GC/FTIR/FID. Chemosphere, 36(14), 2879-2889.

Jenkins, D.A. (1994). Interpretation of interglacial cave sediments from a hominid site in North Wales: Translocation of $\mathrm{Ca}$-Fe phosphates. In A.J. Ringrose-Voase \& G.S. Humphreys (Eds.), Soil micromorphology. Studies in management and Genesis (pp. 293-305). Developments in Soil Science. Amsterdam: Elsevier.

Joris, O., Street, M., Terberger, T., \& Weninger, B. (2011)." Radiocarbon dating the Middle to Upper Palaeolithic transition: The demise of the last Neanderthals and the first appearance of anatomically modern Humans in Europe. In S. Condemi \& G.C. Weniger (Eds.), Continuity and discontinuity in the peopling of Europe: One hundred fifty years of Neanderthal study (pp. 239-298). Springer: Vertebrate Paleobiology and Paleoanthropology.

Karkanas, P. (2001). Site formation processes in Theopetra cave: A record of climatic change during the Late Pleistocene and early Holocene in site formation processes in Theopetra cave. Geoarchaeology: An International Journal, 16(4), 373-399.

Karkanas, P., Bar-Yosef, O., Goldberg, P., \& Weiner, S. (2000). Diagenesis in prehistoric caves: The use of minerals that form in situ to assess the completeness of the archaeological record. Journal of Archaeological Science, 27, 915-929.

Karkanas, P., Rigaud, J.P., Simek, J.F., Albert, M., \& Weiner, S. (2002). Ash bones and guano: A study of the minerals and phytoliths in the sediments of Grotte XVI, Dordogne, France. Journal of Archaeological Science, 29, 721-732.

Le Borgne, E. (1955). Susceptibilité magnétique anormale du' sol superficiel. Annales de géophysique, 11, 399-419.'

Le Pochat, G., Guillot, P.L., Platel, J.P., Recoing, L., \& Texier, J.P. (1979). Carte géologique de la France à 1/50 000, Perigueux-Est (no. 759; 28 p.), BRGM, Orléans, France.'

Lenoble, A., \& Agsous, S. (2012). Abri Pataud-Sédimentogenèse, paléopéedologie, chronologie' des depôts. In P. Bertran \& A. Lenoble (Eds.), Guide book^ of the 2012 AFEQ-ASF field excursion (pp. 4558). Paris: Association Françise pour l'Etude du Quaternaire.

Macphail, R.I., \& Golberg, P. (1999). The soil micromorphological investigation of Westbury cave. Westbury cave. In P. Andrews, J. Cook, A. Currant \& C. Stringer (Eds.), The Natural History Museum excavations 1976-1984 (pp. 59-86). Bristol: Western Academic \& Specialist Press Ltd.

Maher, B., \& Thompson, R. (2009). Mineral magnetic record of the Chinese loess and paleosols. Geology, 19, 3-6. Martini, J., \& Kavalieris, I. (1978). Mineralogy of the Transvaal caves. Transactions of the Geological Society of Africa, 81, 47-54. 
Mellars, P. (2006). A new radiocarbon revolution and the dispersal of modern humans in Eurasia. Nature, 439, 931-945.

Miedema, R., Koulechova, I.N., \& Gerasimova, M.I. (1999). Soil formation in Greyzems in Moscow district: Micromorphology, chemistry, clay mineralogy and particle size distribution. Catena, 34, 315-347.

Mullins, C.E. (1977). Magnetic susceptibility of the soil and its significance in soil science-a review. Journal of Soil Science, 28, 223-246.

Murphy, J., \& Riley, J.P. (1962). A modified single solution method for the determination of phosphate in natural waters. Analytica Chimica Acta, 27(C), 31-36.

Nierop, K.G.J. (1998). Origin of aliphatic compounds in a forest soil. Organic geochemistry, 29(4), 10091016.

Nierop, K.G.J., Van Lagen, B., \& Buurman, P. (2001). Composition of plant tissues and soil organic matter in the first stages of a vegetation succession. Geoderma, 100, 1-24.

Oldfield, F., \& Crowther, J. (2007). Establishing fire incidence in temperate soils using magnetic measurements. Palaeogeography, Palaeoclimatology, Palaeoecology, 249, 362-369.

Peyrony, D. (1934). La Ferrassie. Moustérien, Périgordien,' Aurignacien. Préhistoire, t. III, Paris: E. Leroux.'

Pirson, S., Haesaerts, P., Court-Picon, M., Damblon, F., Toussaint, M., Debenham, M., \& Draily, C. (2006). Belgian cave entrance and rock-shelter sequences as palaeoenvironmental recorders: The example of Walou cave. Geologica Belgica, 9/3(4), 275-286.

Pirson, S., Flas, D., Abrams, G., Bonjean, D., Court-Picon, M., Di Modica, K., Draily, C., Damblon, F., Haesaerts, P., Miller, R., Rougier, H., Toussaint, M., \& Semal, P. (2012). Chronostratigraphic context of the Middle to Upper Palaeolithic transition: Recent data from Belgium. Quaternary International, 289, 78-94.

Poirier, N., Saran, P.S., John, L.G., Mahieu, N., Edward, W.R., David, S.P., \& Richard, P.E. (2005). The chemical composition of measurable soil organic matter pools. Organic geochemistry, 36, 11741189.

Reimer, P.J., Baillie, M.G.L., Bard, E., Bayliss, A., Beck, J.W., Blackwell, P.G., Bronk Ramsey, C., Buck, C.E., Burr, G.S., Edwards, R.L., Friedrich, M., Grootes, P.M., Guilderson, T.P., Hajdas, I., Heaton, T.J., Hogg, A.G., Hughen, K.A., Kaiser, K.F., Kromer, B., McCormac, F.G., Manning, S.W., Reimer, R.W., Richards, D.A., Southon, J.R., Talamo, S., Turney, C.S.M., van der Plicht, J., \& Weyhenmeyer, C.E (2009). IntCal09 and Marine09 radiocarbon age calibration curves, 0-50,000 years cal BP. Radiocarbon, 51(4), 1111-1150.

Rodriguez, C.F., Rego, P.R., \& Cortizas, A.M. (1995). Characterization and depositional evolution of hyena (Crocuta crocuta) coprolites from La Valina cave (northwest Spain). Journal of Archaeological Science, 22, 597-607. 
Rummery, T.A., Bloemendal, J., Dearing, J., \& Oldfield, F. (1979). The persistence of fire-induced magnetic oxides in soils and lake sediments. Annals of Geophysics, 35, 103-107.

Shahack-Gross, R., Berna, F., Karkanas, P., \& Weiner, S. (2004). Bat guano and preservation of archaeological remains in cave sites. Journal of Archaeological Science, 31, 1259-1272.

Simas, F.N.B., Schaefer, C.E.G.R., Melo, V.F., Albuquerque-Filho, M.R., Michel, R.F.M., Pereira, V.V., Gomes, M.R.M., \& da Costa, L.M. (2007). Ornithogenic cryosols from Maritime Antarctica: Phosphatization as a soil forming process. Geoderma, 138, 191-203.

Svensson, A., Andersen, K.K., Bigler, M., Clausen, H.B., Dahl-Jensen, D., Davies S.M., Johnsen S.J., Muscheler, M., Rasmussen, S.O., Rothlisberger, R., Steffensen, J.P., \&“ Vinther, B.M. (2005). The Greenland ice core chronology 2005, 15-42 ka. Part II: Comparison to other records. Quaternary Science Reviews, 25, 3258-3267. USDA. (1999). Soil taxonomy. A Basic system of soil classification for making and interpreting soil surveys, 2nd ed. (871 p.). United States Department of Agriculture, Natural resources Conservation Service. Washington, D.C.

Van Steijn, H., Bertran, P., Francou, B., Hetu, B., \& Texier,' J.P. (1995). Review of models for genetical interpretation of stratified slope deposits. Permafrost and Periglacial Processes, 6, 125-146.

Van Vliet-Lanoe, B. (2011). Frost action. In G. Stoops, V." Marcelino \& F. Mees (Eds.), Interpretation of micromorphological features of soils and regoliths (pp. 81-108). Amsterdam: Elsevier.

Woodward, J.C. (1997). Late Pleistocene rockshelter sedimentation at Klithi. In G.N. Bailey (Ed.), Klithi: Palaeolithic settlement and Quaternary landscapes in northwest Greece. Volume 2: Klithi in its local and regional setting (pp. 361-376). Cambridge: McDonald Institute.

Woodward, J.C., \& Goldberg, P. (2001). The sedimentary records in Mediterranean rockshelters and caves: Archives of environmental change. Geoarchaeology: An International Journal, 16(4), 327354.

Worden, R.H., \& Burley, S.D. (2003). Sandstone diagenesis. The evolution of sand to stone. In S.D. Burley \& R.H. Worden (Eds.), Sandstone diagenesis: Recent and ancient, International Association of Sedimentologists Reprint Series 4 (pp. 3-44). Malden: Wiley-Blackwell Publishing. 